Review

\title{
Physical effects upon whey protein aggregation for nano-coating production
}

\author{
Oscar L. Ramos ${ }^{\mathrm{a}, \mathrm{b}}$, Ricardo N. Pereira ${ }^{\mathrm{a}}$, Rui Rodrigues ${ }^{\mathrm{a}}$, José A. Teixeira ${ }^{\mathrm{a}}$, \\ António A. Vicente ${ }^{a}$, F. Xavier Malcata ${ }^{\text {b,c,* }}$ \\ a CEB - Centre of Biological Engineering, University of Minho, Campus de Gualtar, P-4710-057 Braga, Portugal \\ ${ }^{b}$ LEPABE - Laboratory of Engineering of Processes, Environment, Biotechnology and Energy, University of Porto, Rua Dr. Roberto Frias, P-4200-465 Porto, Portugal \\ c Department of Chemical Engineering, University of Porto, Rua Dr Roberto Frias, P-4200-465 Porto, Portugal
}

\section{A R T I C L E I N F O}

\section{Article history:}

Received 5 July 2014

Accepted 26 September 2014

Available online 12 October 2014

\section{Keywords:}

Whey proteins

Denaturation

Aggregation

Nanostructures

Molecular interaction

Moderate electric field

\begin{abstract}
A B S T R A C T
Production of edible nanostructures constitutes a major challenge in food nanotechnology, and has attracted a great deal of interest from several research fields - including (but not limited to) food packaging. Furthermore, whey proteins are increasingly used as nutritional and functional ingredients owing to their important biological, physical and chemical functionalities. Besides their technological and functional characteristics, whey proteins are generally recognized as safe (GRAS). Denaturation and aggregation kinetics behavior of such proteins are of particular relevance toward manufacture of novel nanostructures possessing a number of potential uses. When these processes are properly engineered and controlled, whey proteins may form nanostructures useful as carriers of bioactive compounds (e.g. antimicrobials, antioxidants and nutraceuticals). This review discusses the latest advances in nano-scale phenomena involved in protein thermal aggregation aiming at formation of bio-based nano-coating networks. The extent of aggregation is dependent upon a balance between molecular interactions and environmental factors; therefore, the impact of these conditions is addressed in a critical manner. A particular emphasis is given to the effect of temperature as long as being one of the most critical variables. The application of moderate electric fields (MEF), an emergent approach, as such or combined with conventional heating is considered as it may inhibit/prevent excessive denaturation and aggregation of whey proteins - thus opening new perspectives for development of innovative protein nanostructures (i.e. nanocoatings). A better understanding of the mechanism(s) involved in whey protein denaturation and aggregation is crucial as it conveys information relevant to select methods for manipulating interactions between molecules, and thus control their functional properties in tailor-made applications in the food industry.
\end{abstract}

(c) 2014 Elsevier Ltd. All rights reserved.

\section{Contents}

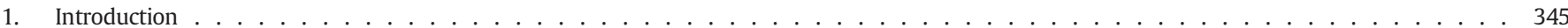

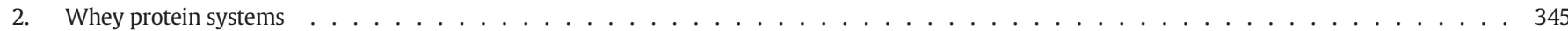

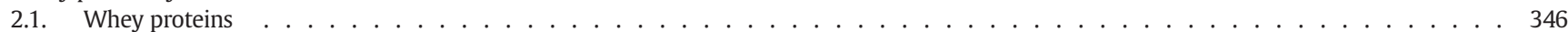

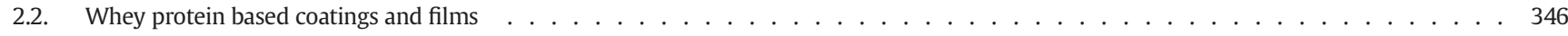

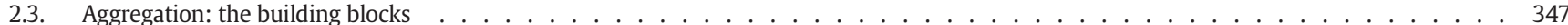

2.4. Molecular interactions . . . . . . . . . . . . . . . . . . . . . . . . . . . . 347

2.5. Effect of environmental factors on protein aggregation _......... 348

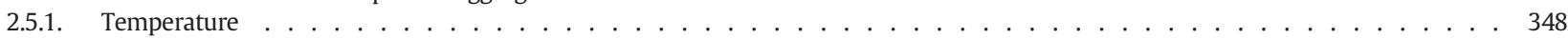

2.5.2. $\mathrm{pH}$ and ionic strength $\ldots \ldots \ldots \ldots \ldots \ldots \ldots$

2.5.3. Protein concentration . . . . . . . . . . . . . . . . . . . . . . . . . . . . . . . . . . . 349

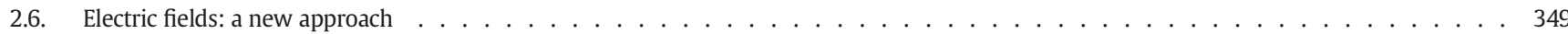

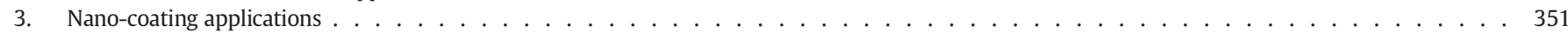

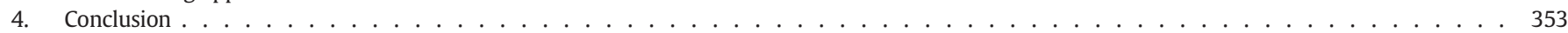

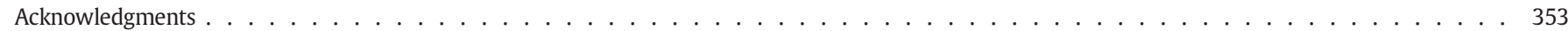

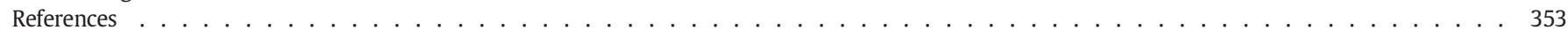

\footnotetext{
* Corresponding author. Tel.: + 351968017411

E-mail address: fmalcata@fe.up.pt (F. Xavier Malcata).
} 


\section{Introduction}

Nanotechnology is a fast emerging field involving design and application of structures or materials where shape and size, at the nanometer scale, are critically controlled (Bouwmeester et al., 2009; Chau, Wu, \& Yen, 2007). The properties of materials at this level can be quite different from conventional-sized materials of the same compound. This behavior arises from the large surface area-to-volume ratio typically found in nano-materials, but also to the influence of physical and chemical interactions between materials at the nano-scale that play a significant role on the overall properties of those systems (Kaya-Celiker \& Mallikarjunan, 2012). These factors may enhance properties, such as strength and reactivity, thus providing different or new functionalities to existing products: enable dispersion of water-insoluble additives (e.g. carotenoids, phytosterols, fatty acids and natural antioxidants), increase stability, allow specific delivery and controlled release of bioactive compounds, and improve adhesion to and absorption rates through cells (Chaudhry, Watkins, \& Castle, 2010; Chen, Remondetto, \& Subirade, 2006). Consequently, assessment of physical and chemical properties is relevant to anticipate possible associated hazards (Bouwmeester et al., 2009).

Application of nanotechnology in the food industry has been receiving increasing attention from the scientific community, and has mainly focused on development of nano-sized ingredients, supplements and additives, as well as nanostructures as carriers of bioactive compounds (e.g. antimicrobials, antioxidants and nutraceuticals) or for incorporation in food packaging (to improve their barrier and mechanical properties) (Chaudhry et al., 2008; Kane \& Stroock, 2007; Weiss, Takhistov, \& McClements, 2006).

Nano-structured systems (e.g. nanoliposomes, nanoemulsions, nanohydrogels, nanotubes, nanofibrils and nano-coatings) are usually characterized according to main material used in manufacture (e.g. polysaccharides, proteins and lipids); production method (e.g. bottomup or top-down); predominant bonds involved (e.g. covalent or noncovalent); main system properties (e.g. mechanical and optical properties); and associated overall free energy (thermodynamically versus kinetically stable systems) (Acosta, 2009; Gutierrez et al., 2008; Lesmes \& McClements, 2009).

Two different building strategies have been used for production of nano-structured systems: 1) "top down" approach, in which nanolevel structures are generated by breaking up bulk materials via milling, nanolithography or precision engineering; and 2) "bottom up" approach, allowing nanostructures to be built from individual atoms or molecules that are capable of self-assembling (Hartgerink, Granja, Milligan, \& Ghadiri, 1996; Moraru et al., 2003; Reches \& Gazit, 2003).

Many synthetic polymers (e.g. polyacrylamide, polyamides, polyphenylesters and polyurethanes) have been successfully used as delivery systems in the biomedical and pharmaceutical areas (Reis, Neufeld, Ribeiro, \& Veiga, 2006). However, these polymers cannot be utilized in food applications that require GRAS (generally recognized as safe) ingredients. Therefore, a major challenge in this area is replacement of non-food-grade materials by bio-based alternatives.

Food biomaterials, specifically polysaccharides (e.g. alginate, carrageenan, pectin, dextran and chitosan), proteins (e.g. zein and whey proteins) and lipids (e.g. medium chain triglycerides, tristearin and corn oil) are reasonable possibilities to address that challenge, since they are biodegradable, food-grade and non-toxic, while allowing also novel functionalities and applications (Acosta, 2009; Morris, 2010; Subirade \& Chen, 2008). However, the use of these polymers has problems associated with their performance and processing, besides cost that are common to most biodegradable food-grade polymers (Garcia, Forbe, \& Gonzalez, 2010). The application of nanotechnology to these polymers may open up new possibilities to improve not only some of their physical limitations, but also their cost-price-efficiency.

Whey protein-based ingredients are widely used in formulated foods because they are by-products from the cheese industry produced to large extents, relatively inexpensive, classified as GRAS materials and having a high nutritional value. Various articles highlight their biological (e.g. digestibility, amino acid profile, high biological value and sensory characteristics) and functional (e.g. emulsification, gelation, foaming and water binding capacity) properties, as well as their application as ingredients in food formulations (Bryant \& McClements, 1998; Clark \& Ross-Murphy, 1987; Dickinson, 2003; Madureira, Pereira, Gomes, Pintado, \& Xavier Malcata, 2007; Walstra, 2003). Among said functional properties, gelation is particularly interesting. Gels of diverse mechanical and microstructural properties can be formed by controlling assembly of protein molecular chains, thus offering the possibility to developing GRAS biocompatible carriers for oral administration of sensitive nutraceuticals in a wide variety of foods.

Nanostructured systems based on whey proteins (e.g. nanocoatings) are interesting because, in addition to their gelling ability, they can be easily prepared, and their size distribution can be effectively monitored. These proteins have also the ability to conjugate nutrients via either primary amino groups, or ionic and hydrophobic binding (Chen et al., 2006). Moreover, several changes can be induced in the whey protein matrix that allow formation of complexes with other biopolymers, chiefly polysaccharides, as starting point for several nanosystems.

Coatings are thin layers of edible material (e.g. whey proteins) directly applied on food aimed at improving surface properties (e.g. appearance, adhesion and wear resistance), while playing an important role upon the preservation of physicochemical and nutritional features of food products, and associated shelf life. A nano-coating is produced through a controlled process at the nano-level, and may significantly enhance the ability of a coating to improve surface properties or even allow new functionalities.

This review will give a crucial insight into the main factors (i.e. temperature, $\mathrm{pH}$, ionic strength, protein concentration and presence of an external electric field) affecting denaturation and aggregation of whey proteins, and therefore into the molecular interactions involved in formation and stabilization of the nano-coatings formed thereof. Understanding of these mechanisms and their mutual relationships is fundamental to control and design structures with intended functionalities. The advantages of application of new approaches, such as moderate electrical fields to control the extent of those processes (denaturation and aggregation), and therefore the size of nanostructures are also addressed. Moreover, several applications of nano-coatings in the food industry are discussed.

\section{Whey protein systems}

The actual and potential use of milk proteins as food ingredients has been a popular topic of research over the past 40 years. Milk and dairy products have numerous advantages over competitors when used as ingredients: they are colorless, have a bland taste, are rather stable to processing and are essentially free of toxins. As ingredients, dairy products are used mainly because of their unique physicochemical properties (Chobert, 2012). Milk is constituted by two major groups of proteins: caseins that are insoluble, remaining stable as a micellar phase in milk, and whey proteins that are soluble. The casein micelles consist of subunits of the different caseins (i.e. $\alpha$-s1, $\alpha$-s2 and $\beta$ ) held together by calcium phosphate bridges on the inside, surrounded by a layer of 6 casein molecules which helps to stabilize the micelle in solution. Micelles are spherical and have 0.04 to $0.3 \mu \mathrm{m}$ in diameter, which are much smaller than fat globules (ca. $1 \mu \mathrm{m}$ in homogenized milk). The casein micelles are porous (allowing the water phase to move freely in and out of the micelle) and stable structures, yet dynamic (i.e. they do not settle out of solution). They can be heated to boiling or cooled, and dried and reconstituted without adverse effects (Holt, Carver, Ecroyd, \& Thorn, 2013). Caseins represent $80 \%$ (w/w) of all milk proteins and can easily be recovered from skim milk through isoelectric precipitation or rennet-driven coagulation. Both techniques release whey as by- 
product - see Fig. 1 (Madureira et al., 2007). Like milk, whey may have different origins (e.g. from cow, goat and sheep) and for that reason this review will address the production of nano-coatings from whey proteins in general; however, some examples and results reported below in Tables 3 and 4 are specific for whey proteins obtained from cow milk processing, once it is the most relevant in terms of production volume and economical value.

\subsection{Whey proteins}

For many years, whey resulting from curd during manufacture of cheese was either regarded as a polluting effluent from the dairy industry, being commonly discarded in rivers or lands (without any treatment) - thus resulting in a serious environmental problem (due to its high production volumes and organic content), or used as animal feed (Bonnaillie \& Tomasula, 2009; Prazeres, Carvalho, \& Rivas, 2012; Tunick, 2009). This paradigm has been changed essentially due to the combination of three critical driving forces: i) legislation; ii) potential of whey proteins; and iii) evolution of technology. In short, legislative regulations together with the consumers' growing concern regarding environmental problems and incentives to recycle whenever possible forced the dairy industry to explore other approaches to manage whey as a waste. Nowadays, the potential of a vast range of whey proteins and that of their peptides is well known, e.g. regarding their health benefits. The developments on separation technologies relying on selective porous membranes allowed a superior isolation and fractionation of whey components, which are undoubtedly becoming one of the most widespread additives in food (Bonnaillie \& Tomasula, 2009; Prazeres

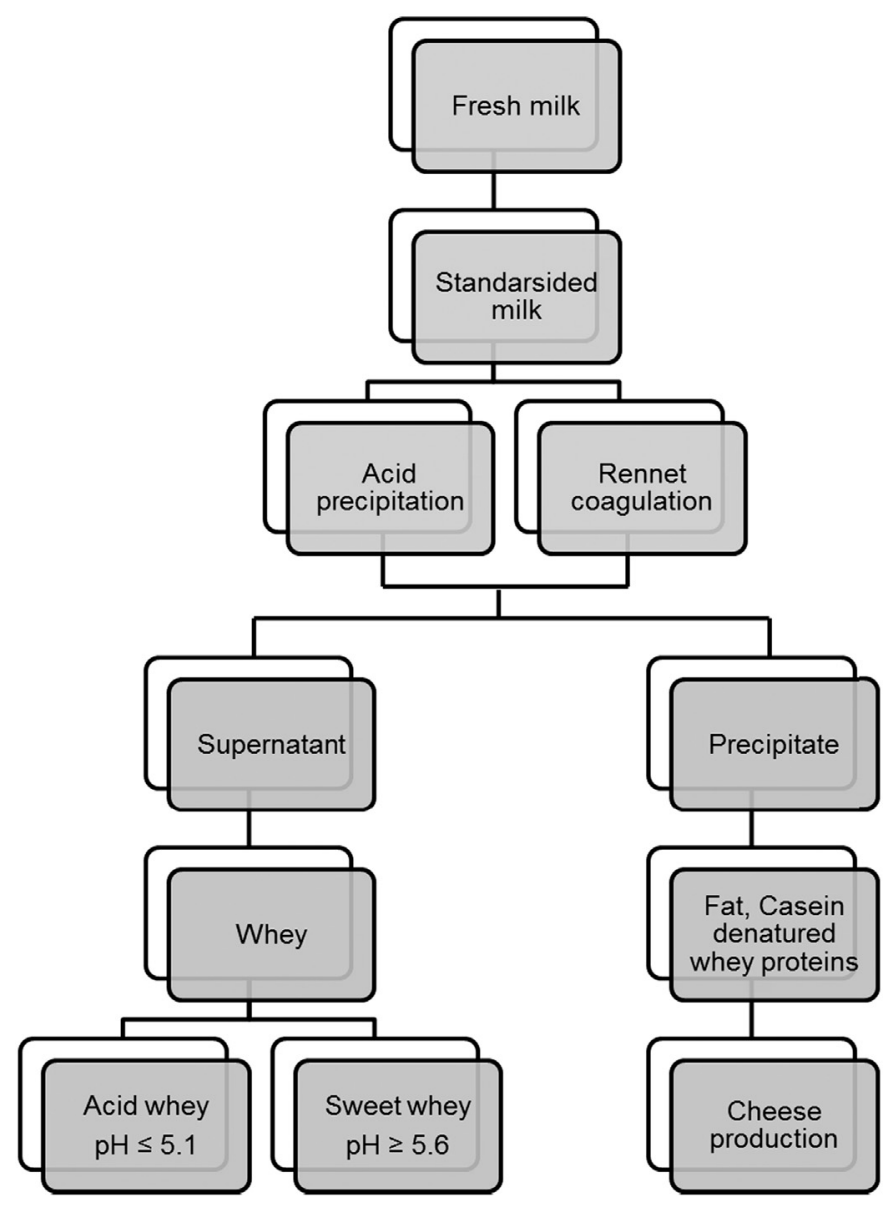

Fig. 1. Schematic diagram of acid and sweet whey production during cheese making. Adapted from Madureira et al. (2007). et al., 2012; Tunick, 2009). Consequently, over the last 40 years the number of commercial and technological applications using whey proteins has increased considerably. Today, they are one of the major sources of commercial protein ingredients (used in confectionery, bakery and ice cream products, infant formulae, health foods, sports drinks and bars) (Wang, Zhong, \& Hu, 2012).

Whey proteins have typically a globular structure (rather susceptible to denaturation by heat), with high levels of secondary and tertiary structures, in which acidic/basic and hydrophobic/hydrophilic amino acids are distributed in a fairly balanced way along their polypeptide chains.

Whey proteins include $\beta$-lactoglobulin $(\beta$ - $\mathrm{Lg}), \alpha$-lactalbumin $(\alpha$ La), immunoglobulins (IG), serum albumin (BSA), proteose peptones (PP), lactoferrin (LF) and lactoperoxidase (LP), together with minor components. Their profile, including general chemical and physicochemical properties, is depicted in Table 1.

With the advent of industrial ultrafiltration and chromatographic techniques, recovery and fractionation of whey proteins in their native forms have become possible. A wide variety of commercial finished whey products are currently available in the market, including whey protein concentrates (WPC) and isolates (WPI), individual and pure whey protein fractions ( $\alpha$-La and $\beta$-Lg, casein glycomacropeptide, BLF and LP) and protein hydrolysates. WPC has protein contents ranging from $35-80 \%(w / w)$, while WPI possesses a minimum protein content of $90 \%(\mathrm{w} / \mathrm{w})$. WPC and WPI are widely used in formulated foods as gelling, surface active or water-binding agents. These whey protein ingredients have unique physicochemical and functional properties (i.e. ability to undergo conformational denaturation, electrostatic charges and amphiphilic nature) besides high nutritional benefits. Their capacity to form foams, emulsions, nano-emulsions, selfassembling structures, hydrogels and nanostructures for delivering bioactive compounds suggests that they may be suitable not only for novel food but also for non-food applications (Chen \& Subirade, 2006; Gunasekaran, Ko, \& Xiao, 2007; Hebrard et al., 2006; Livney, 2010; Ramos, Fernandes, Silva, Pintado, \& Malcata, 2012). Some of the most important types of constraints that govern unfolding and aggregation of $\beta$ - $\mathrm{Lg}$ - that constitutes more than $50 \%(\mathrm{w} / \mathrm{w})$ of the whey proteins, are review below; $\beta$ - $L$ g is indeed the main responsible for gelation and emulsification properties of WPI and WPC. Characteristics of whey protein nano-coatings, molecular interactions and environmental factors that govern protein aggregation are also considered, in view of their being crucial steps for development of nano-coatings.

\subsection{Whey protein based coatings and films}

The concept of coating was derived from observations of the biological kingdom, where many examples of natural protection from mechanical damage and semi-permeable barriers to mass transfer can be ascertained in fruits and vegetables - e.g. cuticle, a natural coating consisting of a layer of cutin. However, modern agricultural practices often damage the integrity of this original coating. To overcome this issue, edible coatings have been formulated and applied to fresh food products to protect from dehydration and quality deterioration. Edible films differ from edible coatings as the former are preformed and freestanding sheets (Chen, 1995).

Considerable interest exists in upgrading of whey protein fractions due to their industrial abundance as feedstock. One of the most promising approaches is the production of edible whey protein coatings and films, aimed at extending shelf life and improving quality changes of heterogeneous foods. This aptitude has been comprehensively reviewed over the last two decades (Chae \& Heo, 1997; Fairley, Monahan, German, \& Krochta, 1996; Gounga, Xu, \& Wang, 2007; Krochta, 2002; Mchugh \& Krochta, 1994). Since edible coatings and films are both a packaging and food component, they are supposed to fulfill a few requirements: display good sensory qualities, high barrier and mechanical efficiencies, enough biochemical, physicochemical and 
Table 1

Composition of major proteins in whey, molecular mass (Mm), isoelectric point (pI), temperature of denaturation (Td) and number of amino acid residues. Adapted from de Wit (2001); Hernández-Ledesma, Ramos, and Gómez-Ruiz (2011); Madureira et al. (2007).

\begin{tabular}{|c|c|c|c|c|}
\hline Whey protein & $\mathrm{Mm}(\mathrm{kDa})$ & $\mathrm{pI}$ & $\operatorname{Td}\left({ }^{\circ} \mathrm{C}\right)$ & Number of amino acid residues \\
\hline$\beta$-Lactoglobulin & 18.3 & 5.2 & 71.9 & 162 \\
\hline$\alpha$-Lactalbumin & 14.2 & 4.8 & 64.3 & 123 \\
\hline Immunoglobulins & $150-900$ & $5.5-6.8$ & - & - \\
\hline Serum albumin & 66.4 & $4.7-4.9$ & $72.0-74.0$ & 583 \\
\hline Proteose peptones & $<12$ & $3.3-3.7$ & - & - \\
\hline Lactoferrin & 80.0 & $8.0-8.5$ & 63.0 and 90.0 & 700 \\
\hline Lactoperoxidase & 78.5 & 9.8 & 70.0 & 612 \\
\hline
\end{tabular}

Note: (-) Variable value.

microbial stability, low cost and simple technological requirements besides being devoid of toxics and safe for health (Debeaufort, Quezada-Gallo, \& Voilley, 1998).

Among other proteins, whey protein fractions offer a great potential for manufacture of edible coatings that can act as moderate barriers to moisture, lipids, oxygen, flavors/aromas, and carriers of food ingredients (e.g. antioxidants, antimicrobials, flavors and nutraceuticals), while improving mechanical integrity or handling characteristics (Krochta, 1992). Coatings obtained from these proteins are generally flavorless, tasteless and flexible materials, and the films made thereof vary from transparent to translucent - depending on formulation, purity of protein source and composition (Chen, 1995; Ramos et al., 2013). Whey protein coatings have been tested on several food products such as peanuts, salmon, fruits or cereals, and were able to offer good aroma, fat, humidity and oxygen barriers (Schmid et al., 2012). The coatingforming substances are able to form a continuous structure by promoting intermolecular interactions among their components; this is crucial to allow the good performance of the coating (e.g. mechanical and barrier properties) once deposited on food surface (Debeaufort et al., 1998). Films and coatings formed from whey proteins involve a complex series of phenomena encompassing dissociation, thermal denaturation and exposure of hydrophobic amino acid residues (Chae \& Heo, 1997; Ramos et al., 2012). These phenomena are influenced by experimental conditions such as protein concentration, $\mathrm{pH}$, heating temperature and ionic strength. The impact of these conditions will be described in the following subsections. Another essential step to be taken into account in formation of whey protein coatings and films is the need to incorporate a minimum content of plasticizer in order to overcome its intrinsic brittleness. Plasticizers function by weakening intermolecular forces between adjacent polymer chains, thus increasing film extensibility and flexibility. However, use of these compounds may decrease elasticity, mechanical resistance and barrier properties of said whey coatings and films (Gounga et al., 2007; Ramos et al., 2013). Polyols, such as glycerol and sorbitol, are the most commonly used plasticizers for manufacture of whey coatings and films.

\subsection{Aggregation: the building blocks}

The high potential for application of whey protein coatings and films in food products is highly dependent on understanding the aggregation behavior of these proteins; once this realization is crucial to control the size of the structures formed, and therefore the level of their functionalities. Protein aggregates serve as building blocks to develop food-grade nano- and micro-network structures. In the food industry, micron-size whey protein aggregates can be used to produce hydrogels with swelling behavior and flow properties, both of which are important for action as a texturizing agent or fat replacer. In turn, nano-size particle aggregates can improve stability of protein foams and emulsions (Guilmineau \& Kulozik, 2006a, 2006b). Whey protein aggregation can be induced by several factors, e.g. addition of chemicals or electrolytes, change in net charge, increase in hydrostatic pressure, partial enzymatic hydrolysis and electrical fields - but mainly by temperature. Each of these processes induces partial (or total) unfolding of the native structure of proteins, thus resulting in protein aggregation and eventual gel formation. Without a heating step, protein networks will hardly form while remaining stable in water (Bodnár, Alting, \& Verschueren, 2007; Pérez-Gago, Nadaud, \& Krochta, 1999; Ramos et al., 2012). Once whey proteins have been heated to a temperature leading to the onset of denaturation, they start to unfold (see Table 1) - and may form different types of aggregates (e.g. fibrillar or particulate aggregates), or remain as individual molecules by balancing attractive and repulsive interactions between them (Pérez-Gago et al., 1999). The extent of aggregation is dependent on extrinsic factors arising from the environment and processing conditions. Aggregation is a prerequisite for formation of whey protein nano-coatings; when properly controlled and engineered, it often results in novel materials with interesting functionalities (Matalanis, Jones, \& McClements, 2011; Zuniga, Tolkach, Kulozik, \& Aguilera, 2010).

Gelling typically includes linking of polymeric chains, leading to a progressively larger embranchment of molecules - yet polymers may be soluble, depending on network density, structure and conformation of starting material. The aggregation of polydisperse soluble ramified polymers is called 'sol'. Continuous crosslinking increases the size of the ramified polymer chains, thus decreasing their solubility. This continuous building process is called 'gelation', and ends up in polymer formation. Transition from aggregation to a continuous building process is called 'sol-gel transition' (or gelation) - and the critical point where gel first appears is called 'gel point' (Pethrick, 2004).

\subsection{Molecular interactions}

Different kinds of energetic molecular interactions drive and stabilize conformation and assembly of proteins. These can be covalent or non-covalent, repulsive or attractive, and long- or short-range. Protein structures can be involved in several types of interactions, such as hydrophobic, van der Waals and hydrogen-bridges. These interactions are mainly reversible and weak, but if applying on a larger and cooperative scale, the overall interactions may turn to be strong. Interactions allow formation of disulfide bridges, leading to covalent stabilization of the resulting particle aggregates. Distinct molecular interactions between protein molecules have been reviewed elsewhere (Bryant \& McClements, 1998; Pérez-Gago et al., 1999), and are summarized in Table 2.

Hydrogen bonds stabilize aggregates formed, but are not usually the major driving force determining conformation and aggregation of globular proteins (Croguennec, O'Kennedy, \& Mehra, 2004).

Conversely, intermolecular hydrophobic interactions are temperaturedependent and constitute the major force in controlling protein aggregation. One of the characteristic features of hydrophobic interactions is their tendency to increase in strength as temperature is raised (de Wit, 1990). Globular proteins, such as $\beta$-Lg, are stabilized by electrostatic repulsions. These interactions depend on sign, magnitude and distribution of charge on a protein molecule, which are governed by the $\mathrm{pH}$ and ionic strength of surrounding aqueous solution. Electrostatic repulsion between proteins may be modified by adding electrolytes or adjusting $\mathrm{pH}$ to the isoelectric point (pI) (Kinsella \& Whitehead, 
Table 2

Types of molecular interactions between protein molecules in aqueous solution.

Adapted from Bryant \& McClements (1998).

\begin{tabular}{|c|c|c|c|c|c|c|c|}
\hline Interaction & Type $^{\mathrm{a}}$ & Strength & Sign & Range & $\mathrm{pH}$ & Ionic strength & Temperature \\
\hline Disulfide bonds & $\mathrm{C}$ & Very strong & Attractive & Short & Yes & No & $\uparrow$ \\
\hline Hydrophobic & NC & Strong & Attractive & Long & No & No & $\uparrow$ \\
\hline Steric repulsion & $\mathrm{NC}$ & Strong & Repulsive & Short & No & No & - \\
\hline Hydration & $\mathrm{NC}$ & Strong & Repulsive & Short & $\mathrm{No}^{\mathrm{b}}$ & $\mathrm{No}^{\mathrm{b}}$ & $\downarrow$ \\
\hline Electrostatic & $\mathrm{NC}$ & Weak to strong ${ }^{\mathrm{c}}$ & Repulsive & Short to long ${ }^{c}$ & Yes & $\downarrow$ & $\uparrow$ \\
\hline Hydrogen bonds & NC & Weak & Attractive & Short & No & No & $\downarrow$ \\
\hline van der Walls & NC & Weak & Attractive & Short & No & No & - \\
\hline
\end{tabular}

Note:

( $\uparrow$ Increase; $(\downarrow)$ decrease; - no information available.

a Covalent (C) and non-covalent (NC).

b Indirectly depends on $\mathrm{pH}$ and IS.

c Depends on $\mathrm{pH}$ and ionic strength (IS).

1989): at their pI, proteins possess no net charge (Table 1); above or below they are negatively and positively charged, respectively. The magnitude and range of these interactions can be reduced considerably in the presence of electrolytes due to electrostatic suppression (i.e. interactions between charges are reduced in strength) induced by counter-ions (Kitabatake, Wada, \& Fujita, 2001). Electrostatic interactions between charged protein molecules increase in strength with increasing temperature due to their entropic basis (Pérez-Gago et al., 1999).

Disulfide bonds result from rearrangement of the $\beta$ - $L$ g tertiary structure. When $\beta$-Lg starts to unfold due to denaturation, Cys121 (a free sulfhydryl $(\mathrm{SH})$ group buried in the native structure of $\beta-\mathrm{Lg}$ ) is the first to become exposed to aqueous phase (initiation step) and therefore the first being able to react through $\mathrm{SH}$ /disulfide interchange reactions with existing disulfide bonds (Cys66-Cys160 and Cys106-Cys119) that are present in $\beta$-Lg. These intermolecular disulfide bridges give rise to a propagation reaction that results in the aggregation process (Croguennec, Bouhallab, Molle, O'Kennedy, \& Mehra, 2003).

Interactions during hydration may prevent aggregation of protein molecules since stronger repulsion and longer interaction range are promoted when hydration level is high.

Steric interactions are intrinsically related to possible conformations of proteins in solution: in this regard, molecules cannot adopt any spatial arrangements in which two or more segments occupy the same space. There is an extremely strong repulsive interaction between atoms or molecules at close separations, because of the overlap of their electron clouds. This determines how closely they can pack together - and also defines the size and shape of aggregates of atoms and molecules (Pérez-Gago et al., 1999).

Van der Waals interactions appear to present similar magnitudes irrespective of protein conformation state (folded or unfolded), thus playing a minor role in aggregation mechanisms. However, if the protein molecule is large enough to act as a colloidal particle, then aggregation with other biopolymer molecules is likely to happen due to a strong van der Waals attraction (Bryant \& McClements, 1998).

\subsection{Effect of environmental factors on protein aggregation}

\subsubsection{Temperature}

Temperature (when increased) may promote several additional destabilizing effects upon the thermodynamic stability of proteins. These effects include reduction of activation energy, increased protein diffusion and frequency of molecular collisions - besides enhancement of hydrophobic interactions, which are necessary steps for the occurrence of physical protein aggregation. Consequently, high temperature is a common parameter selected to accelerate protein aggregation (Bryant \& McClements, 1998). Under physiological conditions, $\beta$ - Lg exists as a non-covalently linked dimer stabilized by hydrogen bonds; each monomer of this globular protein has one free $\mathrm{SH}$ group that is normally hidden in the hydrophobic interior of the protein. The tertiary structure of $\beta-\mathrm{Lg}$ is strongly stabilized by two disulfide bonds (Cys66Cys160 and Cys106-Cys119), which seem to play an important role in denaturation (Croguennec et al., 2003; de Wit, 1998; Kitabatake et al., 2001). Denaturation of $\beta$ - $\mathrm{Lg}$ is generally assumed to be a multistage process consisting of (at least) two steps: 1 ) unfolding of native protein; and 2 ) irreversible aggregation of unfolded protein. The initiation step of heat-induced denaturation of $\beta-\mathrm{Lg}$ at neutral $\mathrm{pH}$ involves reversible dissociation of $\beta-\operatorname{Lg}$ native dimers to native monomers at a temperature above $40{ }^{\circ} \mathrm{C}$. Close to $60{ }^{\circ} \mathrm{C}$, the native monomers undergo intramolecular transition into a so-called R-state that differs from the native state only by minor conformational changes of some side chains. When temperature of the protein solution increases above $60{ }^{\circ} \mathrm{C}, \beta$ - $\mathrm{Lg}$ undergoes conformational changes and partially unfolds, thus exposing hydrophobic amino acids and thereby increasing the hydrophobic attraction between them.

The major forces that control protein aggregation are intermolecular hydrophobic interactions that are temperature-dependent (de Wit, 1990; Mulvihill \& Donovan, 1987). Under almost neutral conditions, aggregation is irreversibly induced by heat through a three-step process (Bodnár et al., 2007): (1) initiation, (2) propagation, and (3) termination. During initiation, the free SH groups that are normally buried at the interface between native monomers, become exposed to further reaction (Zuniga et al., 2010). At this point, reshuffling of intramolecular disulfide bonds may be responsible for formation of irreversible nonnative monomers with free SH at position Cys119 (Croguennec et al., 2003; Croguennec et al., 2004). Following initiation of aggregation by hydrophobic forces, the propagation step corresponds to buildup of aggregates through inter- and intramolecular disulfide bonding - via SHdisulfide interchange or oxidation reactions. Disulfide bonding is known to play an important role in strengthening of aggregates (Pérez-Gago et al., 1999). The reactive SH group of non-native monomers reacts via a SH/disulfide bond exchange reaction with one of the two intramolecular disulfide bonds of a non-denatured monomer to form a dimer; an intermolecular disulfide bond is then formed and a new reactive free SH group is now available on the originally non-denatured molecule. In turn, the reactive dimer can react similarly with a non-denatured monomer, and this propagation step can be repeated several times, thus increasing the size of the polymer chain. These aggregates apparently assume a linear organization due conformation of $\beta-\mathrm{Lg}$ and conformational changes occurring during propagation - only one of the two intra-molecular disulfide bonds and only one SH group/monomer are supposed to be reactive (Bodnár et al., 2007). Finally, aggregation stops (termination step) when two active intermediates (i.e. multimers) react to form aggregates without an exposed, reactive $\mathrm{SH}$ group. Formation of intermolecular disulfide bonds by $\mathrm{SH}$-disulfide interchange is considered one of the major mechanisms of protein aggregation, and it is apparently governed by formation of $\beta$ - $\mathrm{Lg}$ oligomers that combine into aggregates (Mulvihill \& Donovan, 1987). However, the mechanism by which unfolding and protein aggregation take place is complex, and may be influenced by many factors. In addition to $\mathrm{SH} /$ 
disulfide bond exchange reactions enabled by reactive free $\mathrm{SH}$ groups, different types of molecular non-covalent interactions (e.g. hydrophobic/electrostatic of non-native molecules) of $\beta$ - $\operatorname{Lg}$ molecules take place irreversibly and form larger aggregates - the building blocks of whey protein nanostructures. Recently, it was shown that together with other factors such as $\mathrm{pH}$, ionic strength or protein concentration, the type of heating method (direct or indirect) used for whey protein denaturation should not be underestimated, once it influences the viscoelastic dynamic behavior of whey protein isolate gels obtained therefrom (Rodrigues et al., in press). This work has shown that slight differences on the patterns of thermal denaturation/aggregation at nano-scale have great impact on the physical properties of protein network structures.

\subsection{2. $\mathrm{pH}$ and ionic strength}

The occurrence and extent of protein aggregation can be controlled by the processing conditions, such as time versus temperature treatment applied (as it affects the level of denaturation imposed). However, a variety of other environmental factors besides temperature can significantly impact the aggregation behavior of proteins. These include chemical environment of aqueous solution (protein concentration, $\mathrm{pH}$ and ionic strength), addition of salts (cold gelation) and even influence of external electrical stimuli (Debeaufort et al., 1998; Pereira, Souza, Cerqueira, Teixeira, \& Vicente, 2010). Among these, pH dictates the type and distribution of surface charges on proteins, affecting both intramolecular folding and intermolecular protein-protein interactions. Therefore, $\mathrm{pH}$ along with sequence hydrophobicity and propensity to form secondary structures are key parameters in determining the rate of protein aggregation (Bryant \& McClements, 1998).

Ionic strength is another key condition intrinsically related to $\mathrm{pH}$, which largely affects protein aggregation. Both positive and negative ions may bind or interact electrostatically with proteins that will change interactions between charges, or even induce different conformational states. This may generate different aggregation behaviors and morphologies of protein aggregates. The salt type to adjust ionic strength is another condition not to be neglected. Divalent cations, such as calcium and magnesium, can induce aggregation in three different ways: (1) electrostatic shielding; (2) ion/hydrophobic interactions; and (3) crosslinking with negatively charged carboxylic groups of neighboring whey protein molecules, via protein-cation-protein bridges. On the other hand, monovalent cations affect aggregation mainly by reducing repulsions between negatively charged molecules, thus allowing molecules to come closer to each other. This promotes formation of noncovalent associations and covalent disulfide bonds between protein molecules (Mulvihill \& Donovan, 1987). In this sense, solutions with identical ionic strength but different salt types can undergo distinct aggregation behaviors. Moreover, divalent ions need lower concentrations to promote aggregation than monovalent ones, because they have higher effectiveness at suppressing electrostatic interactions and ability to form salt bridges.

The balance between $\mathrm{pH}$ and ionic strength on $\beta$ - $\mathrm{Lg}$ solutions has been widely investigated for production of different types of $\beta-\mathrm{Lg}$ hydrogels - transparent or turbid gel. The so-called fine-stranded gel is composed of finely stranded nanometer-thick networks, exhibiting transparent or translucent appearance and rubbery texture. It is formed under conditions where intermolecular electrostatic repulsion is dominant, known to occur at low ionic strength and $\mathrm{pH}$ values are far from $\mathrm{pl}$ $(\mathrm{pI} \approx 5.2)$. Intermolecular repulsion can be decreased by shifting $\mathrm{pH}$ toward the $\mathrm{pI}$ or by increasing ionic strength. At these conditions, aggregation is accelerated by heat, and leads to formation of a turbid or white opaque gel composed of micrometer-sized particulate random aggregates (Chen, 1995; Gounga et al., 2007; Ko \& Gunasekaran, 2009).

\subsubsection{Protein concentration}

The effect of protein concentration upon protein aggregation has been extensively discussed (Bryant \& McClements, 1998). Regarding whey proteins, increasing protein concentration often results in:
(1) increased aggregation due to increased chance of protein-protein interactions; and (2) precipitation due to solubility limit. When a salt is added to a heat-denatured protein solution, the concentration of protein has a major influence on the rheological properties of the solution; at low protein concentration, the heat-denatured protein will tend to form a viscous solution, but above the critical protein concentration a gel is obtained - cold gelation (Pérez-Gago et al., 1999).

\subsection{Electric fields: a new approach}

Several technologies using moderate electrical fields (MEF) are currently being applied on food, on a commercial scale, for thermal processing of a wide range of products. During MEF treatment, electric energy passes through food that behaves as a resistance in an electrical circuit; hence, the heating occurs in the form of internal energy transformation (from electric to thermal) within the material (Sastry \& Barach, 2000). MEF technology, also known as ohmic heating (Machado, Pereira, Martins, Teixeira, \& Vicente, 2010) can be distinguished from other electrical heating methods by: a) presence of electrodes contacting the food; b) range of frequency applied (ca. 50-25,000 Hz); and c) unrestricted, and typically sinusoidal waveform. MEF treatments provide uniform and extremely rapid heating rates of liquids that enable the application of higher temperatures without inducing coagulation or excessive denaturation of proteins (Parrott, 1992). Aseptic processing of fluids of high viscosity and fluids containing particulates has been promising applications of MEF in the food industry (Palaniappan \& Sastry, 2002). However, during the last decade, some authors (Perez \& Pilosof, 2004; Xiang, Ngadi, Ochoa-Martinez, \& Simpson, 2011) reported that application of pulsed electric fields (PEF) of high intensity (typically $20-80 \mathrm{kV} \cdot \mathrm{cm}^{-1}$ ) can modify the structure/function of whey proteins - in order to achieve specific and/or desired functional properties in a manner similar to use of controlled heat treatments. MEF is a process characterized by a relatively low electric field (arbitrarily restricted to between 1 and $1000 \mathrm{~V} \cdot \mathrm{cm}^{-1}$ ) as compared to PEF used to control permeabilization and other non-thermal effects (Machado et al., 2010). Application of MEF has, in particular, been sought by researchers in the production of protein-based structured systems, e.g. edible films, coatings and hydrogels. Recently, it has been reported that the presence of MEF has statistically significant effects on chitosan coating physical properties and structure, with consequences on film transport properties (Souza et al., 2009, 2010). A heating method based on application of MEF has also been used as a device for protein-lipid coating formation. The use of MEF produced less heat damage to coating forming solution, prevented overcooking and reduced structural disruption - while improving yield, rehydration capacity and film formation rate (Lei, Zhi, Xiujin, Takasuke, \& Zaigui, 2007). Given the complex biochemical structure of whey proteins, the influence of MEF on their mechanisms of unfolding (denaturation) and aggregation has been recently assessed through a kinetic and thermodynamic approach (Pereira, Teixeira, \& Vicente, 2011). This work demonstrates that MEF processing offers the potential to reduce whey protein denaturation at relatively high temperatures when combined with a fast come-up-time (CUT), which is the time needed to reach a desired temperature. In respect to this, Table 3 shows values of $k$ (rate constant), $n$ (reaction order), $D$ and $t_{1 / 2}$ (time required for 90 and $50 \%$ protein denaturation, respectively) obtained from kinetic analysis of the denaturation process of WPI. In general, authors have observed that MEF treatments presented lower values of $n$ and $k(p<0.05)$, being this difference more pronounced when MEF treatment at temperatures ranging at $90{ }^{\circ} \mathrm{C}$ is combined with a CUT of $5 \mathrm{~s}$ at the beginning of the heating cycle. As expected, $D$ and $t_{1 / 2}$ values decreased with the increase of heating temperature. However at $90{ }^{\circ} \mathrm{C}$ under the influence of MEF, treatments with CUTs of 37 and $5 \mathrm{~s}$ presented higher $D$ values $(p<0.05)$ than the ones obtained with conventional heating $(0 \mathrm{~V} /$ $\mathrm{cm})$. With regard to $t_{1 / 2}$, at temperatures of $75^{\circ} \mathrm{C}$ all treatments presented nearly the same value $(p>0.05)$, whereas at temperatures 
Table 3

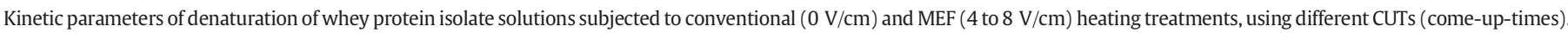

\begin{tabular}{|c|c|c|c|c|c|}
\hline Treatment & $\mathrm{T}\left({ }^{\circ} \mathrm{C}\right)$ & $N^{1}$ & $K^{2}\left(\mathrm{~s}^{-1} \cdot 10^{3}\right)$ & $t_{1 / 2}^{3}(\min )$ & $D^{4}(\min )$ \\
\hline $\left.0 \mathrm{~V} / \mathrm{cm}_{(\mathrm{CUT}}=100 \mathrm{~s}\right)$ & 75 & $1.7 \pm 0.1^{\mathrm{a}}$ & $3.8 \pm 1.0^{\mathrm{a}}$ & $4.0 \pm 0.9^{\mathrm{a}}$ & $25.0 \pm 3.0^{\mathrm{a}}$ \\
\hline 4 to $\left.8 \mathrm{~V} / \mathrm{cm}_{(\mathrm{CUT}}=100 \mathrm{~s}\right)$ & & $1.4 \pm 0.3^{\mathrm{a}}$ & $2.3 \pm 0.2^{\mathrm{a}}$ & $5.9 \pm 0.1^{\mathrm{a}}$ & $28.8 \pm 6.6^{\mathrm{a}}$ \\
\hline 4 to $\left.8 \mathrm{~V} / \mathrm{cm}_{(\mathrm{CUT}}=37 \mathrm{~s}\right)$ & & $1.3 \pm 0.1^{\mathrm{a}}$ & $2.1 \pm 0.5^{\mathrm{a}}$ & $6.2 \pm 1.1^{\mathrm{a}}$ & $26.6 \pm 1.1^{\mathrm{a}}$ \\
\hline 4 to $\left.8 \mathrm{~V} / \mathrm{cm}_{(\mathrm{CUT}}=5 \mathrm{~s}\right)$ & & $1.2 \pm 0.1^{\mathrm{a}}$ & $1.8 \pm 0.2^{\mathrm{a}}$ & $6.7 \pm 0.6^{\mathrm{a}}$ & $25.4 \pm 1.0^{\mathrm{a}}$ \\
\hline $\left.0 \mathrm{~V} / \mathrm{cm}_{(\mathrm{CUT}}=100 \mathrm{~s}\right)$ & 80 & $2.0 \pm 0.1^{\mathrm{a}}$ & $13.1 \pm 1.2^{\mathrm{a}}$ & $1.3 \pm 0.1^{\mathrm{a}}$ & $11.0 \pm 2.0^{\mathrm{a}}$ \\
\hline 4 to $\left.8 \mathrm{~V} / \mathrm{cm}_{(\mathrm{CUT}}=100 \mathrm{~s}\right)$ & & $1.4 \pm 0.1^{\mathrm{b}}$ & $6.1 \pm 0.8^{\mathrm{b}}$ & $2.2 \pm 0.2^{\mathrm{b}}$ & $10.5 \pm 0.7^{\mathrm{a}}$ \\
\hline 4 to $\left.8 \mathrm{~V} / \mathrm{cm}_{(\mathrm{CUT}}=37 \mathrm{~s}\right)$ & & $1.2 \pm 0.1^{\mathrm{b}, \mathrm{c}}$ & $4.8 \pm 0.1^{b}$ & $2.6 \pm 0.0^{\mathrm{b}, \mathrm{c}}$ & $10.2 \pm 1.0^{\mathrm{a}}$ \\
\hline 4 to $\left.8 \mathrm{~V} / \mathrm{cm}_{(\mathrm{CUT}}=5 \mathrm{~s}\right)$ & & $1.2 \pm 0.0^{\mathrm{c}}$ & $4.6 \pm 0.4^{\mathrm{b}}$ & $2.7 \pm 0.2^{\mathrm{c}}$ & $10.5 \pm 0.6^{\mathrm{a}}$ \\
\hline $\left.0 \mathrm{~V} / \mathrm{cm}_{(\mathrm{CUT}}=100 \mathrm{~s}\right)$ & 85 & $2.2 \pm 0.2^{\mathrm{a}}$ & $39.7 \pm 4.8^{\mathrm{a}}$ & $0.6 \pm 0.0^{\mathrm{a}}$ & $5.4 \pm 1.2^{\mathrm{a}}$ \\
\hline 4 to $\left.8 \mathrm{~V} / \mathrm{cm}_{(\mathrm{CUT}}=100 \mathrm{~s}\right)$ & & $1.7 \pm 0.1^{\mathrm{b}}$ & $17.4 \pm 1.6^{\mathrm{b}}$ & $0.9 \pm 0.1^{b}$ & $5.4 \pm 0.4^{\mathrm{a}}$ \\
\hline 4 to $\left.8 \mathrm{~V} / \mathrm{cm}_{(\mathrm{CUT}}=37 \mathrm{~s}\right)$ & & $1.4 \pm 0.1^{\mathrm{c}}$ & $11.2 \pm 1.2^{\mathrm{c}}$ & $1.2 \pm 0.1^{\mathrm{c}}$ & $5.7 \pm 0.4^{\mathrm{a}}$ \\
\hline 4 to $8 \mathrm{~V} / \mathrm{cm}($ CUT $=5 \mathrm{~s})$ & & $1.0 \pm 0.0^{\mathrm{d}}$ & $7.1 \pm 0.2^{c}$ & $1.6 \pm 0.0^{\mathrm{d}}$ & $5.4 \pm 0.1^{\mathrm{a}}$ \\
\hline $\left.0 \mathrm{~V} / \mathrm{cm}_{(\mathrm{CUT}}=100 \mathrm{~s}\right)$ & 90 & $2.2 \pm 0.1^{\mathrm{a}}$ & $106.0 \pm 10.2^{\mathrm{a}}$ & $0.2 \pm 0.0^{\mathrm{a}}$ & $1.9 \pm 0.2^{\mathrm{a}}$ \\
\hline 4 to $\left.8 \mathrm{~V} / \mathrm{cm}_{(\mathrm{CUT}}=100 \mathrm{~s}\right)$ & & $2.1 \pm 0.0^{\mathrm{a}, \mathrm{b}}$ & $71.8 \pm 7.4^{\mathrm{b}}$ & $0.2 \pm 0.0^{\mathrm{a}}$ & $2.5 \pm 0.1^{\mathrm{a}, \mathrm{b}}$ \\
\hline 4 to $8 \mathrm{~V} / \mathrm{cm}(\mathrm{CUT}=37 \mathrm{~s})$ & & $1.7 \pm 0.1^{\mathrm{b}}$ & $33.1 \pm 1.2^{\mathrm{c}}$ & $0.5 \pm 0.0^{\mathrm{b}}$ & $2.9 \pm 0.1^{\mathrm{b}}$ \\
\hline 4 to $\left.8 \mathrm{~V} / \mathrm{cm}_{(\mathrm{CUT}}=5 \mathrm{~s}\right)$ & & $1.3 \pm 0.2^{c}$ & $18.4 \pm 1.8^{\mathrm{c}}$ & $0.7 \pm 0.0^{c}$ & $3.2 \pm 0.3^{\mathrm{b}}$ \\
\hline
\end{tabular}

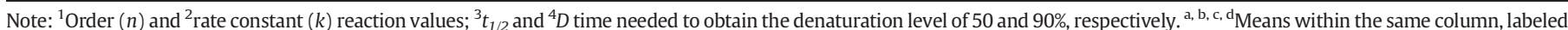
with the same letter, are not statistically different from each other $(p>0.05)$.

ranging from 80 to $90{ }^{\circ} \mathrm{C}$, significant differences were noted $(p<0.05)$ among the treatments (Pereira et al., 2011). The authors concluded that with application of MEF, denaturation reactions seem to be less dependent on temperature increase, thus improving the thermodynamic stability of whey proteins. In this sense, MEF technology may play a major role on the interfacial, aggregation and gelation properties of whey proteins, since they are intrinsically related to protein denaturation and protein-protein interactions.

Application of MEF for production of WPI nano-coatings and films has been studied by Pereira et al. (2010). Table 4 summarizes the main results of this study regarding the characterization of WPI solutions before and after heating treatments - in terms of average hydrodynamic diameter of particles $(Z)$, polydispersity index $(P D I)$ and presence of free reactive sulfhydryl groups (SH). When WPI solutions were heated $\left(85^{\circ} \mathrm{C}\right.$, up to $30 \mathrm{~min}$ ), the $Z$ of the whey protein aggregates was found to increase considerably when the conventional treatment (without MEF, $0 \mathrm{~V} / \mathrm{cm}$ ) and MEF treatment at $10 \mathrm{~V} / \mathrm{cm}$ were applied, when compared with the unheated samples. However, MEF at $10 \mathrm{~V} /$ $\mathrm{cm}$ produced smaller changes $(p<0.05)$ in whey protein aggregates' size when compared with conventional heating $(0 \mathrm{~V} / \mathrm{cm})$. Overall, the whey protein aggregates' diameter increased by about 57 and $67 \mathrm{~nm}$ during MEF and conventional heating, respectively. The PDI reached an identical plateau ( $p>0.05$ ) of ca. 0.27 in both heating treatments. Regarding the presence of $\mathrm{SH}$ groups, it was observed that residual quantities were present in unheated WPI solutions $(0.6 \mu \mathrm{mol}$ of SH per gram of WPI). However, at the end of heating treatments, concentrations of SH in WPI solution were about 10 times higher than those observed in unheated WPI solutions. Results also show that samples treated by conventional heating (no MEF applied) had $26 \%$ more micromoles of SH per gram of WPI than samples treated at $10 \mathrm{~V} / \mathrm{cm}(p<0.05)$. The authors concluded that despite MEF treatments promoting the unmasking of SH groups in whey proteins upon extended heat treatment, the conformational disturbances, molecular interactions and associations of denatured proteins upon application of an external electrical field need to be

Table 4

Characterization of whey protein isolate (WPI) solutions before and after heating treatments; in terms of average hydrodynamic diameter of particles $(Z)$, polydispersity index $(P D I)$ and presence of free reactive sulfhydryl groups (SH).

\begin{tabular}{lllc}
\hline & \multicolumn{2}{l}{ WPI aggregates } & $\begin{array}{c}\text { Reactive-SH } \\
\left(\mu \mathrm{mol} \mathrm{SH} \cdot \mathrm{g}^{-1} \text { WPI }\right)\end{array}$ \\
\cline { 2 - 3 } & $Z(\mathrm{~nm})$ & $P D I$ & \\
\hline Unheated & $19.4 \pm 2.8^{\mathrm{a}}$ & $0.71 \pm 0.10^{\mathrm{a}}$ & $0.6 \pm 0.0^{\mathrm{a}}$ \\
$0 \mathrm{~V} / \mathrm{cm}$ & $86.0 \pm 0.5^{\mathrm{b}}$ & $0.27 \pm 0.01^{\mathrm{b}}$ & $10.7 \pm 0.4^{\mathrm{b}}$ \\
$10 \mathrm{~V} / \mathrm{cm}$ & $76.6 \pm 0.5^{\mathrm{c}}$ & $0.27 \pm 0.00^{\mathrm{b}}$ & $8.5 \pm 0.1^{\mathrm{c}}$ \\
\hline
\end{tabular}

Note: ${ }^{\mathrm{a}, \mathrm{b}, \mathrm{c}}$ Means within the same column, labeled with the same letter, are not statistically different from each other $(p>0.05)$. further studied and verified (Pereira et al., 2010). In agreement with this study, at neutral $\mathrm{pH}$ conditions and low protein concentrations, MEF determined a lower increase of whey protein aggregate size and reactive free $\mathrm{SH}$ than conventional heating. MEF coating-forming solutions were used to produce edible films through incorporation of a minimum content of plasticizer. WPI films produced by MEF presented specific physical and structural properties, e.g. lower thickness and less permeability to water vapor, higher availability of hydrophilic groups, and nearly the same mechanical properties of conventional films after drying (Pereira et al., 2010). These results can be explained by different patterns of denaturation, interaction and aggregation of whey proteins. Among other factors, reorientation of hydrophobic clusters in the protein structure during heating may have promoted a higher availability of hydrophilic groups. Moreover, aggregation and consequently viscosity of cast solutions may have played an important role in establishing the thickness of MEF coatings. All these changes can be correlated with conformational changes found in protein secondary structures of the film network. Fourier self-deconvolution and curve-fitting of FTIR (Fourier transform infra-red) absorbance spectra, taken in the range of the amide I region and corresponding to MEF treatment of $10 \mathrm{~V} / \mathrm{cm}$ and conventional heating $(0 \mathrm{~V} / \mathrm{cm})$, are depicted in Fig. 2 . Deconvolution results of the amide I region showed that MEF coatings have higher contents of $\beta$-sheet structure than conventional ones (Pereira et al., 2010).

Therefore, MEF influences the unfolding and aggregation mechanisms of whey proteins during heating, thus changing distribution of secondary protein structures. This behavior can be related to conformational disturbances on tertiary protein structure due to rearrangement of hydrogen bonds, hydrophobic interactions and ionic bonds. Further, non-covalent interactions may also be impaired by reorientation of hydrophobic clusters in protein structure during MEF application, thus affecting physical aggregation. MEF treatment may also affect ionic movement in the medium, and modify molecular environment due to increased number of ions and their different distributions around protein molecules.

Alternatively, the combined effects of MEF and sinusoidal electrical frequency may promote splitting of large aggregates induced by thermal processing, thus enhancing formation of small protein particles. Because of the opposite effects of these treatments (thermal and electric), it appears possible to control the size of whey protein structures by simultaneously manipulating the temperature and intensity of electric field applied. However, more experimental data are needed to fully address the role of MEF on protein electrostatics and protein-protein interactions.

Recently it was shown by Rodrigues et al. that application of MEF during heating treatment may offer a great potential to the 


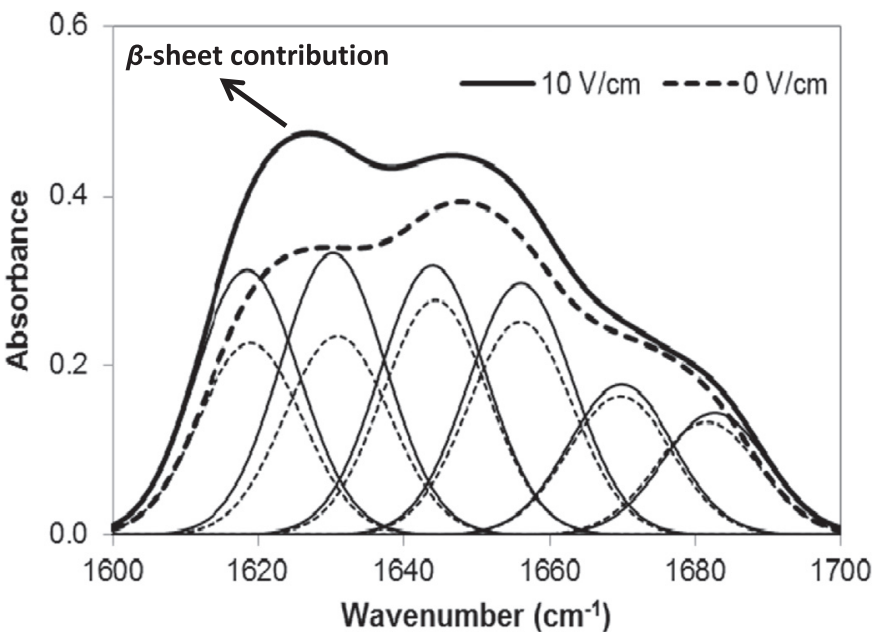

Fig. 2. Fourier self-deconvolution and curve-fitting of FTIR absorbance spectra, taken in attenuated total reflectance (ATR) mode in the range of amide I region; deconvoluted $(-)$ and original (-) spectra: the bands at 1619,1630 and $1683 \mathrm{~cm}^{-1}$ correspond to $\beta$ sheet structures; bands at 1644 and $1652 \mathrm{~cm}^{-1}$ correspond to unordered and $\alpha$-helix structures, respectively; and bands at $1670 \mathrm{~cm}^{-1}$ correspond to turns. Adapted from Pereira et al. (2010).

development of GRAS whey protein network structures with diverse mechanical and microstructural features and hence improved textural properties. Heating combined with application of MEF may bring implications on the quality, and functional and technological properties of whey-derived products (Rodrigues et al., in press). MEF may open a new perspective for manufacture of protein nano-coatings with tailored functional and technological properties. A more complete study should thus be developed to better understand how electric fields interact at a molecular level with individual whey proteins, thus clarifying the events occurring during unfolding and aggregation. The effects of MEF processing on the structural properties and functionality of $\beta$ - $\mathrm{Lg}$ are indeed a challenge that remains to be addressed.

\section{Nano-coating applications}

Food packaging is one of the main focus of polymer nanotechnology and thus one of the major applications of nano-coatings once it is believed that this technology can implement and improve all the principal functions of existing packaging (Silvestre, Duraccio, \& Cimmino, 2011). Depending on the type of food, packaging materials need to fulfill different requirements in terms of light, moisture, water vapor and gas (i.e. oxygen and carbon dioxide) barriers in order to avoid color or taste deterioration, loss of nutritional value and eventually growth of potential pathogens (Fabra, López-Rubio, \& Lagaron, 2014).

Whey is one of the most promising biopolymers in the field of packaging. Currently, the best potential applications of whey protein-based edible films lie in protective coatings for foods. When applied upon surfaces of food as a coating, these films can provide protection from chemical or microbial degradation, thus lengthening product shelf life and maintaining high product quality (Dangaran, Tomasula, \& Qi, 2009). Further, edible films and coatings manufactured from whey proteins have shown better mechanical and barrier properties than competitive protein-based (e.g. corn zein, wheat gluten and soy protein isolate) or polysaccharide-based (e.g. starch, cellulose, carrageenan and pectin) films (Ramos et al., 2012).

Whey protein coatings were already applied in several food products such as peanuts, frozen salmon, fruits, or cereals, aiming at providing good aroma, fat, moisture and gas oxygen barriers. They also have potential to improve the appearance of food products by adding gloss. Several examples of whey protein-based coating applications are described (Khwaldia, Perez, Banon, Desobry, \& Hardy, 2004; Kilara \& Vaghela, 2004; Schmid et al., 2012).

However, the properties of whey protein coatings at macro-scale can be quite different from those prevailing at nano-scale. The use of nanocoatings is expected to improve mechanical and barrier properties when incorporated in edible food packaging, as well as to provide new functionalities - therefore strengthening the basis for innovative applications in the food industry (Chaudhry et al., 2010; Chen et al., 2006) as described below, and summarized in Fig. 3.

Since one of the main functions of food packaging is to avoid or decrease water loss, water vapor permeability (WVP) should be as low as possible (Gontard, Guilbert, \& Cuq, 1992). Several factors have been shown to influence WVP, including coating composition, coating thickness and the technique used for coating application (Bifani et al., 2007). Therefore, the application of nano-coatings can be of great usefulness for food packaging once their significantly reduced thickness may improve barrier properties while exchanging their resistance, flexibility and tension, as well as the food appearance. The amount of information available regarding the applications of nano-coatings made only from whey proteins is rather limited, therefore several examples are provided regarding coatings made also from other materials (e.g. polysaccharides and complex formed by proteins and polysaccharides).

For instance, Pinheiro et al. produced nano-coatings using two polysaccharides (i.e. א-carrageenan and chitosan), by a layer-by-layer (LbL) self-assembly technique. These nanolayered coatings exhibited lower WVP and oxygen permeability $\left(\mathrm{O}_{2} \mathrm{P}\right)$ values (Pinheiro et al., 2012) when compared with those obtained for conventional edible films composed of chitosan (Fajardo et al., 2010) and of l-carrageenan (Hambleton, Debeaufort, Beney, Karbowiak, \& Voilley, 2008) - see Table 5. Also, the K-carrageenan/chitosan nanolayered coating showed a WVP value which was very similar to that obtained for an alginate/chitosan (Carneiro-da-Cunha et al., 2010) and к-carrageenan/lysozyme (Medeiros et al., 2012) nanolayered coating (see Table 5).

The excess of water at the surface of food products or high water activity products promotes bacterial and mold growth, whereas excess of oxygen may cause oxidation, which may lead to several food alterations such as odor, color, flavor and nutrient deterioration (Sothornvit \& Pitak, 2007). Therefore, increasing water vapor and oxygen barriers by the application of nanolayered coatings may contribute to maintain or improve the overall quality and the shelf life of foods (Sothornvit \& Pitak, 2007).

Moreover, nano-coating materials may provide other active functionalities such as antimicrobial activity. An antimicrobial multilayer coating made from hen egg white lysozyme as base material was developed to provide antimicrobial activity, inhibiting the growth of a model microorganism (Micrococcus luteus) in the surrounding medium (Rudra, Dave, \& Haynie, 2006).

The potential applications of antimicrobial nano-coatings made from whey proteins and peptides have been reported in several works, using different foods. For instance, a nano-laminate coating made from $\kappa$ carrageenan and lysozyme was applied on 'Rocha' (Pyrus communis L.) fresh-cut and whole pears (Medeiros et al., 2012) and another similar structure produced from alginate and lysozyme was applied on 'Coalho' cheese (Medeiros et al., 2014); their results showed that nano-coatings assembled on both types of surfaces (fruit and 'Coalho' cheese) had a positive effect on the overall quality of those foods and contributed to extend their shelf life.

Food preservation is a nuclear concept for the food industry and so the antimicrobial properties exhibited by these nanostructures are extremely important, and may be used to enhance considerably the shelf life of other perishable food products such as processed meats, cheese, confectionery, and fresh fruits and vegetables (Moraru et al., 2003) see Fig. 3.

Whey protein nano-coatings can also act as sensors mainly intended to monitor the condition of packaged food or the environment surrounding the food. This technology can provide real-time status of 


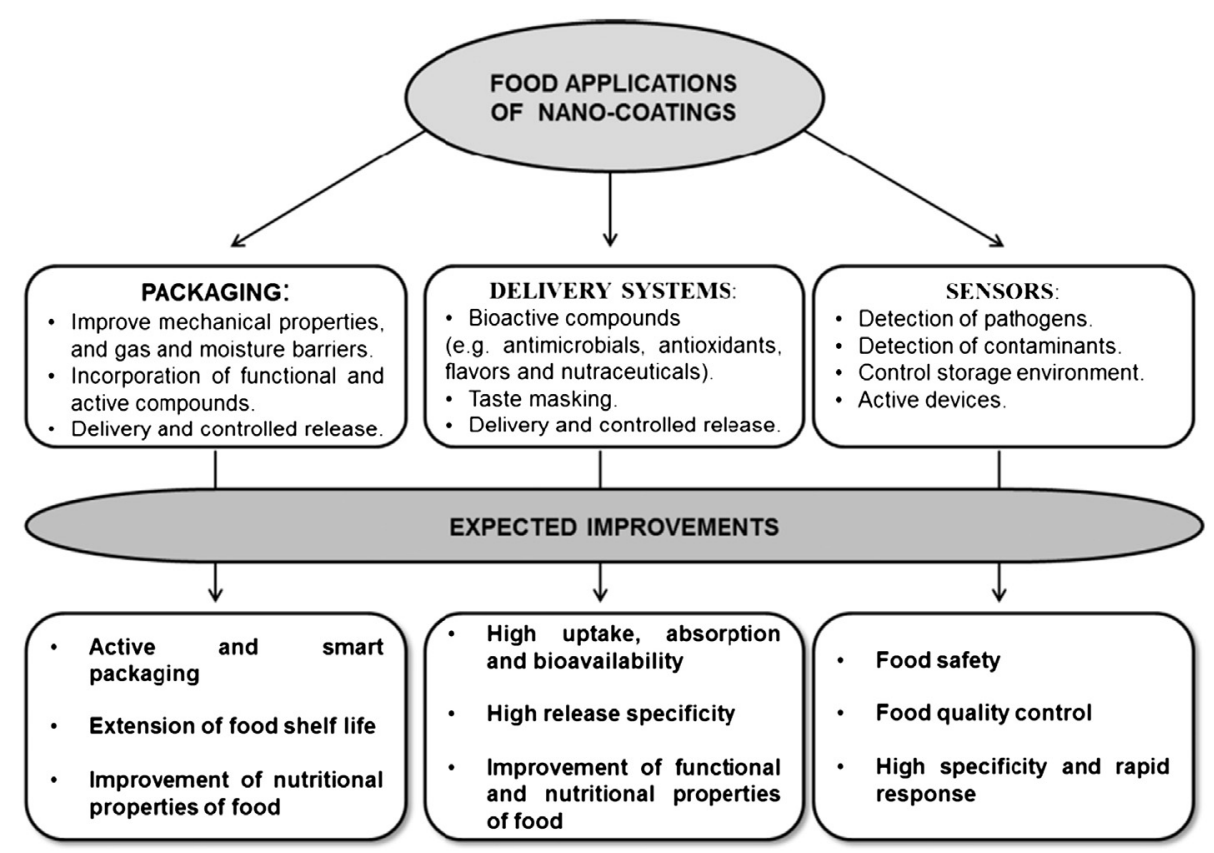

Fig. 3. Potential applications of nano-coatings in the food industry.

food freshness by using a visible indicator (i.e. thousands of nanocoatings may be designed to fluoresce in different colors upon contact with food pathogens, chemical contaminants, or toxins in response to changes in environmental conditions e.g. $\mathrm{pH}$, temperature and moisture), thus informing the supplier or the consumer that foodstuffs are still fresh, or whether the packaging has been breached, kept at the appropriate temperatures throughout the supply chain, or has spoiled see Fig. 3 (Garcia et al., 2010). Taking into account the crucial importance of time in food microbiology, the main aim of these nanostructures is to reduce time for pathogen detection from day-level to hour or even minute-level. Nano-coatings could be placed directly into the food products, and be used to detect chemicals released during food spoilage (or even pathogens) in real time - see Fig. 3 (Garcia et al., 2010).

Other potential functionalities of whey protein nano-coatings include acting as delivery vectors of functional (e.g. plasticizers, emulsifiers and oils) and bioactive (e.g. antimicrobials, antioxidants, vitamins, probiotics and bioactive peptides) compounds (previously incorporated into the packaging material), thus enhancing safety, or even nutritional and sensory attributes of food (Letchford \& Burt, 2007; Taylor, Davidson, Bruce, \& Weiss, 2005) - as highlighted in Fig. 4.

The reduced size of nano-coatings coupled with the intrinsic properties of whey protein including biological (e.g. digestibility, amino acid pattern, high biological value and sensory characteristics), functional (e.g. emulsification, gelation and foaming) and structural (an interior network for the incorporation of active compounds and an extraordinary binding capacity to those compounds through electrostatic, van-der Waals and/or hydrophobic interactions between the agent and the protein matrix), leads to the formation of stable nanostructures, in which such compounds become entrapped (Cerqueira et al., 2013; Huang et al., 2004; Sahiner et al., 2007).

Whey protein nano-coatings are also able to produce a predetermined response (e.g. changing their permeability to entrapped compounds or even disintegrate) to the alteration of certain environmental stimuli - e.g. temperature, pH, electric fields, ionic strength or enzymatic conditions, at a desired point and time (Filipcsei, Csetneki, Szilágyi, \& Zrínyi, 2007; Liu \& Urban, 2010; Shiga, 1997; Zhao et al., 2009). These stimuli-sensitive nano-coatings are of great interest since their behavior can be easily and rapidly changed by external environmental conditions, e.g. allowing a controlled and specified release of entrapped compounds in specific sites of action. This permits e.g. maintaining sufficient (but not excessive) concentrations of a given compound for long periods of time, thus avoiding premature degradation and undesirable chemical reactions, as well as increasing solubility and bioavailability (especially for those compounds with poor solubility in aqueous matrices or with poor absorption rates, such as carotenoids, phytosterols, $\omega-3$ fatty acids, natural antioxidants, flavors and colors) (Cerqueira et al., 2013; Said, Abd Alla, \& El-Naggar, 2004; Schuetz, Gurny, \& Jordan, 2008).

Zimet and Livney developed a stable nano-coating made from a complex of protein-polysaccharide (i.e. $\beta$-Lg-pectin) for encapsulation and delivery of hydrophobic nutraceuticals such as $\omega-3$ fatty acids

Table 5

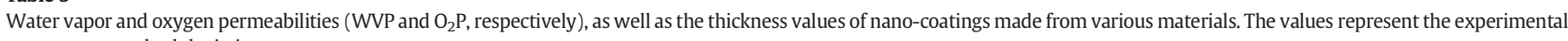
average \pm standard deviation.

\begin{tabular}{|c|c|c|c|c|}
\hline Nano-coating based materials & $\begin{array}{l}\text { WVP } \times 10^{-11} \\
\left(\mathrm{~g} \mathrm{~m}^{-1} \mathrm{~s}^{-1} \mathrm{~Pa}^{-1}\right)\end{array}$ & $\begin{array}{l}\mathrm{O}_{2} \mathrm{P} \times 10^{-14} \\
\left(\mathrm{~g} \mathrm{~m}^{-1} \mathrm{~s}^{-1} \mathrm{~Pa}^{-1}\right)\end{array}$ & $\begin{array}{l}\text { Thickness } \\
(\mu \mathrm{m})\end{array}$ & References \\
\hline К-Carrageenan/chitosan & $0.020 \pm 0.002$ & $0.043 \pm 0.027$ & 100 & Pinheiro et al. (2012) \\
\hline Chitosan & $8.60 \pm 0.14$ & $0.71 \pm 0.02$ & 50 & Fajardo et al. (2010) \\
\hline ı-Carrageenan & $11.80 \pm 0.30-235 \pm 19.8^{\mathrm{a}}$ & $720 \pm 280$ & 50 & Hambleton et al. (2008) \\
\hline Alginate/chitosan & $0.014 \pm 0.001$ & - & 0.12 & Carneiro-da-Cunha et al. (2010) \\
\hline К-Carrageenan/lysozyme & $0.013 \pm 0.003$ & - & 0.47 & $\begin{array}{l}\text { Medeiros, Pinheiro, Teixeira, Vicente, } \\
\text { and Carneiro-da-Cunha (2012) }\end{array}$ \\
\hline
\end{tabular}

Note: - No information available.

a Depending on temperature and humidity gradient. 


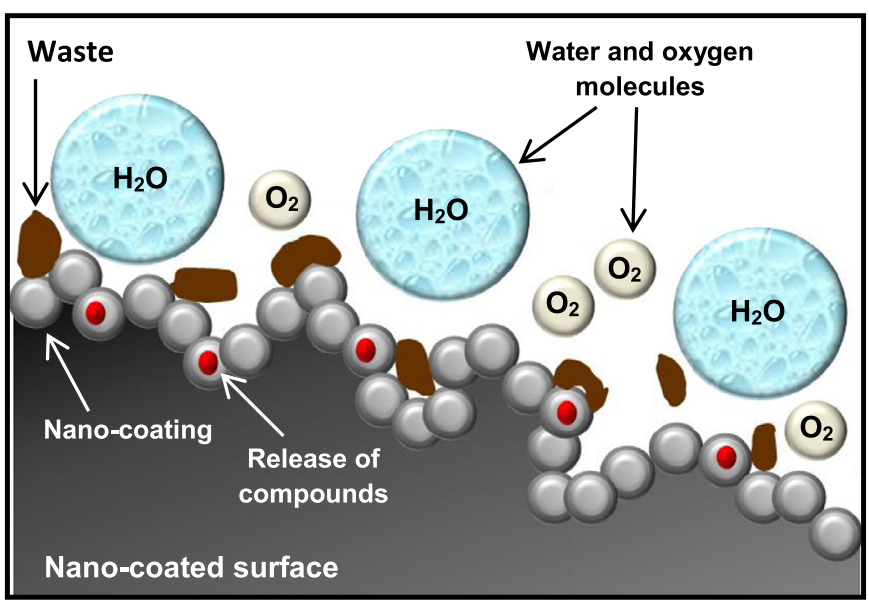

Fig. 4. Schematic representation of nano-coatings functionalities (e.g. semi-permeable barrier to oxygen $\left(\mathrm{O}_{2}\right)$ and water $\left(\mathrm{H}_{2} \mathrm{O}\right)$, barrier to waste and a vehicle for delivery and release of $(\bullet$ ) bioactive compounds) when deposited on the surface of a food product.

(DHA). These authors observed that this nanosystem entrapped efficiently DHA molecules producing a stable system able to protect DHA against oxidation, thus imparting health-improving properties to beverages and food products during storage (Zimet \& Livney, 2009). Also, Somchue used $\beta-\mathrm{Lg}$ and hen egg white protein as a base matrix system for encapsulation of $\alpha$-tocopherol. In order to protect and avoid the release of $\alpha$-tocopherol in harsh gastric conditions, alginate was used as external coating for these encapsulated nanostructures. Those authors observed that it was possible to protect and maintain the stability of this bioactive compound using a protein based-material (Somchue, Sermsri, Shiowatana, \& Siripinyanond, 2009). Bengoechea prepared nano-coatings from bovine LF capable to resist subsequent $\mathrm{pH}$ (from 3 to 11) and salt (from 0 to $200 \mathrm{mM} \mathrm{NaCl}$ ) alterations, being useful as carrier systems or functional ingredients in food products (Bengoechea, Jones, Guerrero, \& McClements, 2011). Li designed the encapsulation of epigallocatechin-3-gallate (EGCG), a potent antioxidant obtained from green tea, in nano-coatings of $\beta$-Lg. A stable and clear nanosystem was observed and the highest protection of EGCG antioxidant activity was obtained with $\beta-\operatorname{Lg}$ heated at $85{ }^{\circ} \mathrm{C}$ and at the molar ratio of $1: 2$ ( $\beta$-Lg:EGCG) (Li, Du, Jin, \& Du, 2012).

Additionally whey protein nano-coatings can also reduce the gastrointestinal (GI) mucosa irritation caused by continuous contact with some active compounds. This happens due to the specified delivery to the associated tissues and controlled release properties coupled with the bio-adhesive features, and assures stability of such compounds in the GI tract while increasing their bioavailability in the mucus of the intestinal epithelium (Kopeček, 2003; Lin \& Metters, 2006; Oh, Lee, \& Park, 2009; Tokarev \& Minko, 2009; Vermonden, Censi, \& Hennink, 2012).

Arbós et al. designed nano-coatings made from BSA as base material and verified that those nanostructures present bioadhesive properties allowing specific interaction with target sites in the organism and consequently a more efficient release of active compounds than other carrier systems (Arbós, Arangoa, Campanero, \& Irache, 2002).

Modulation of surface properties, coupled with theses bioadhesive features is another important intrinsic capability of whey protein nano-coatings that permit specific targeted delivery of bioactive compounds, or increase their bioavailability in the mucus of the intestinal epithelium (Bouwmeester et al., 2009; Chen et al., 2006; Medina, Santos-Martinez, Radomski, Corrigan, \& Radomski, 2007).

\section{Conclusion}

Nanotechnology has become increasingly important in the food sector. Production of edible food-grade nanostructures remains a major challenge, but promising results and applications have already being shown in food packaging, food delivery systems and food safety.

Development of nanostructured systems made from whey proteins is particularly interesting because such a feedstock is not only a valuable by-product largely available from the cheese industry and thus relative inexpensive, but also owing to its classification as GRAS, high nutritional value and several unique functional properties. The capacity of whey proteins to form gel is especially important for development of nanocoatings. Production of whey-based edible coatings is affected by amino acid composition, distribution and polarity of proteins, and environmental conditions affecting molecular interactions between them (e.g. ionic crosslinking between amino and carboxyl groups, presence of hydrogen bonding, and intramolecular and disulfide bonds).

Crosslinking induced by thermal denaturation is an essential step in formation of whey protein-based coatings. However, unfavorable environmental conditions (e.g. extreme $\mathrm{pH}$, or low protein or salt concentration) may impair the initiation steps of protein aggregation. Moreover, emergent processing methods, such as MEF, may be applied in order to change the functional properties of protein matrices. Convenient methods to manipulate interactions between protein molecules and, therefore, to control the size of nanostructures formed and their functional properties are in order.

The incorporation of nano-coatings into food packaging may improve their mechanical and barrier properties, and should thereby help reduce the use of valuable raw materials - a generation of waste. Several changes can be induced in the whey protein matrix, thus allowing complexes with other biopolymers to be formed as a basis for several nanostructures. The development of nano-coatings for delivery of bioactive compounds (via binding those agents through either primary amino groups or ionic/hydrophobic forces) and for acting as sensors of microorganisms and contaminants toward detection is also an important area that has receiving increasing attention by the food industry.

\section{Acknowledgments}

Oscar L. Ramos and Ricardo N. Pereira gratefully acknowledge PostDoctoral grants (SFRH/BPD/80766/2011 and SFRH/BPD/81887/2011, respectively) by Fundação para a Ciência e Tecnologia (FCT, Portugal). All authors thank the FCT Strategic Project PEst-OE/EQB/LA0023/2013 and Project "BioEnv - Biotechnology and Bioengineering for a sustainable world", REF. NORTE-07-0124-FEDER-000048, co-funded by Programa Operacional Regional do Norte (ON.2 - O Novo Norte), QREN, FEDER.

\section{References}

Acosta, E. (2009). Bioavailability of nanoparticles in nutrient and nutraceutical delivery. Current Opinion in Colloid E' Interface Science, 14(1), 3-15. http://dx.doi.org/10.1016/ j.cocis.2008.01.002.

Arbós, P., Arangoa, M.A., Campanero, M.A., \& Irache, J.M. (2002). Quantification of the bioadhesive properties of protein-coated PVM/MA nanoparticles. International Journal of Pharmaceutics, 242(1-2), 129-136. http://dx.doi.org/10.1016/s03785173(02)00182-5.

Bengoechea, C., Jones, O.G., Guerrero, A., \& McClements, D.J. (2011). Formation and characterization of lactoferrin/pectin electrostatic complexes: Impact of composition, $\mathrm{pH}$ and thermal treatment. Food Hydrocolloids, 25(5), 1227-1232. http://dx.doi.org/10. 1016/j.foodhyd.2010.11.010.

Bifani, V., Ramírez, C., Ihl, M., Rubilar, M., García, A., \& Zaritzky, N. (2007). Effects of murta (Ugni molinae Turcz) extract on gas and water vapor permeability of carboxymethylcellulose-based edible films. LWT - Food Science and Technology, 40(8), 1473-1481. http://dx.doi.org/10.1016/j.lwt.2006.03.011.

Bodnár, I., Alting, A.C., \& Verschueren, M. (2007). Structural effects on the permeability of whey protein films in an aqueous environment. Food Hydrocolloids, 21(5-6), 889-895. http://dx.doi.org/10.1016/j.foodhyd.2006.11.017.

Bonnaillie, L.M., \& Tomasula, P.M. (2009). Whey protein fractionation. Whey processing, functionality and health benefits (pp. 15-38). Wiley-Blackwell.

Bouwmeester, H., Dekkers, S., Noordam, M.Y., Hagens, W.I., Bulder, A.S., de Heer, C., et al. (2009). Review of health safety aspects of nanotechnologies in food production. Regulatory Toxicology and Pharmacology, 53(1), 52-62. http://dx.doi.org/10.1016/j. yrtph.2008.10.008. 
Bryant, C.M. \& McClements, D.J. (1998). Molecular basis of protein functionality with special consideration of cold-set gels derived from heat-denatured whey. Trends in Food Science E Technology, 9(4), 143-151. http://dx.doi.org/10.1016/S0924-2244(98) 00031-4.

Carneiro-da-Cunha, M.G., Cerqueira, M.A., Souza, B.W.S., Carvalho, S., Quintas, M.A.C. Teixeira, J.A., et al. (2010). Physical and thermal properties of a chitosan/alginate nanolayered PET film. Carbohydrate Polymers, 82(1), 153-159. http://dx.doi.org/10. 1016/j.carbpol.2010.04.043.

Cerqueira, M., Pinheiro, A., Silva, H., Ramos, P., Azevedo, M., Flores-López, M., et al. (2013). Design of bio-nanosystems for oral delivery of functional compounds. Food Engineering Reviews, 1-19. http://dx.doi.org/10.1007/s12393-013-9074-3.

Chae, S. -I., \& Heo, T. -R. (1997). Production and properties of edible film using whey protein. Biotechnology and Bioprocess Engineering, 2(2), 122-125. http://dx.doi.org/10. 1007/bf02932339.

Chau, C. -F., Wu, S. -H., \& Yen, G. -C. (2007). The development of regulations for food nanotechnology. Trends in Food Science E Technology, 18(5), 269-280. http://dx.doi. org/10.1016/j.tifs.2007.01.007.

Chaudhry, Q., Scotter, M., Blackburn, J., Ross, B., Boxall, A., Castle, L., et al. (2008). Applications and implications of nanotechnologies for the food sector. Food Additives and Contaminants, 25(3), 241-258. http://dx.doi.org/10.1080/02652030701744538.

Chaudhry, Q., Watkins, R., \& Castle, L. (2010). Nanotechnologies in the food arena: New opportunities, new questions, new concerns. In Q. Chaudhry, L. Castle, \& R. Watkins (Eds.), Nanotechnologies in food, Vol. RSC Nanoscience E Nanotechnology, Royal Society of Chemistry.

Chen, H. (1995). Functional properties and applications of edible films made of milk proteins. Journal of Dairy Science, 78(11), 2563-2583. http://dx.doi.org/10.3168/jds. S0022-0302(95)76885-0.

Chen, L., Remondetto, G.E., \& Subirade, M. (2006). Food protein-based materials as nutraceutical delivery systems. Trends in Food Science and Technology, 17 272-283.

Chen, L.Y., \& Subirade, M. (2006). Alginate-whey protein granular microspheres as oral delivery vehicles for bioactive compounds. Biomaterials, 27(26), 4646-4654. http:// dx.doi.org/10.1016/j.biomaterials.2006.04.037.

Chobert, J. -M. (2012). Milk protein tailoring to improve functional and biological properties. Journal of BioScience and Biotechnology, 1(3).

Clark, A., \& Ross-Murphy, S. (1987). Structural and mechanical properties of biopolymer gels. Biopolymers, Vol. 83. (pp. 57-192). Berlin Heidelberg: Springer.

Croguennec, T., Bouhallab, S., Molle, D., O'Kennedy, B.T., \& Mehra, R. (2003). Stable monomeric intermediate with exposed Cys-119 is formed during heat denaturation of beta-lactoglobulin. Biochemical and Biophysical Research Communications, 301(2), 465-471 (doi: S0006291X02029972 [pii]).

Croguennec, T., O'Kennedy, B.T., \& Mehra, R. (2004). Heat-induced denaturation/aggregation of beta-lactoglobulin A and B: Kinetics of the first intermediates formed. International Dairy Journal, 14(5), 399-409. http://dx.doi.org/10.1016/j.idairyj.2003. 09.005 .

Dangaran, K., Tomasula, P.M., \& Qi, P. (2009). Structure and function of protein-based edible films and coatings. In M.E. Embuscado, \& K.C. Huber (Eds.), Edible films and coatings for food applications. London New York: Springer Dordrecht Heidelberg.

de Wit, J.N. (1990). Thermal-stability and functionality of whey proteins. Journal of Dairy Science, 73(12), 3602-3612.

de Wit, J.N. (1998). Nutritional and functional characteristics of whey proteins in food products. Journal of Dairy Science, 81(3), 597-608. http://dx.doi.org/10.3168/jds. S0022-0302(98)75613-9.

de Wit, J. N. (2001). Lecturer's handbook on whey and whey products. Brussels, Belgium: European Whey Products Association.

Debeaufort, F., Quezada-Gallo, J.A., \& Voilley, A. (1998). Edible films and coatings: Tomorrow's packagings: A review. [Historical Article Review]. Critical Reviews in Food Science and Nutrition, 38(4), 299-313. http://dx.doi.org/10.1080/ 10408699891274219.

Dickinson, E. (2003, November 24). Colloidal aggregation: Mechanism and implications. In E. Dickinson, \& T. v. Vlie (Eds.), Food colloids, biopolymers and materials (1st ed.). Royal Society of Chemistry.

Fabra, M.J., López-Rubio, A., \& Lagaron, J.M. (2014). 15 - Biopolymers for food packaging applications. In M.R. Aguilar, \& J.S. Román (Eds.), Smart polymers and their applications (pp. 476-509). Woodhead Publishing.

Fairley, P., Monahan, F.J., German, J.B., \& Krochta, J.M. (1996). Mechanical properties and water vapor permeability of edible films from whey protein isolate and $\mathrm{N}$-ethylmaleimide or cysteine. Journal of Agricultural and Food Chemistry, 44(12), 3789-3792.

Fajardo, P., Martins, J.T., Fuciños, C., Pastrana, L., Teixeira, J.A., \& Vicente, A.A. (2010). Evaluation of a chitosan-based edible film as carrier of natamycin to improve the storability of Saloio cheese. Journal of Food Engineering, 101(4), 349-356. http://dx. doi.org/10.1016/j.jfoodeng.2010.06.029.

Filipcsei, G., Csetneki, I., Szilágyi, A., \& Zrínyi, M. (2007). Magnetic field-responsive smart polymer composites. Oligomers - Polymer composites - Molecular imprinting, Vol. 206. (pp. 137-189). Berlin Heidelberg: Springer.

Garcia, M., Forbe, T., \& Gonzalez, E. (2010). Potential applications of nanotechnology in the agro-food sector. Ciência e Tecnologia de Alimentos, 30(3), 573-581. http://dx. doi.org/10.1590/S0101-20612010000300002.

Gontard, N., Guilbert, S., \& Cuq, J. -L. (1992). Edible wheat gluten films: Influence of the main process variables on film properties using response surface methodology. Journal of Food Science, 57(1), 190-195. http://dx.doi.org/10.1111/j.1365-2621.1992. tb05453.x.

Gounga, M.E., Xu, S. -Y., \& Wang, Z. (2007). Whey protein isolate-based edible films as affected by protein concentration, glycerol ratio and pullulan addition in film formation. Journal of Food Engineering, 83(4), 521-530. http://dx.doi.org/10.1016/j. jfoodeng.2007.04.008.
Guilmineau, F., \& Kulozik, U. (2006a). Impact of a thermal treatment on the emulsifying properties of egg yolk. Part 1: Effect of the heating time. Food Hydrocolloids, 20(8), 1105-1113. http://dx.doi.org/10.1016/j.foodhyd.2005.12.005.

Guilmineau, F., \& Kulozik, U. (2006b). Impact of a thermal treatment on the emulsifying properties of egg yolk. Part 2: Effect of the environmental conditions. Food Hydrocolloids, 20(8), 1114-1123. http://dx.doi.org/10.1016/j.foodhyd.2005.12.006.

Gunasekaran, S., Ko, S., \& Xiao, L. (2007). Use of whey proteins for encapsulation and controlled delivery applications. Journal of Food Engineering, 83(1), 31-40. http://dx.doi. org/10.1016/j.jfoodeng.2006.11.001.

Gutierrez, J.M., Gonzalez, C., Maestro, A., Sole, I., Pey, C.M., \& Nolla, J. (2008). Nano-emulsions: New applications and optimization of their preparation. Current Opinion in Colloid \& Interface Science, 13(4), 245-251. http://dx.doi.org/10.1016/j.cocis.2008.01. 005.

Hambleton, A., Debeaufort, F., Beney, L., Karbowiak, T., \& Voilley, A. (2008). Protection of active aroma compound against moisture and oxygen by encapsulation in biopolymeric emulsion-based edible films. Biomacromolecules, 9(3), 1058-1063. http://dx.doi.org/10.1021/bm701230a.

Hartgerink, J.D., Granja, J.R., Milligan, R.A., \& Ghadiri, M.R. (1996). Self-assembling peptide nanotubes. Journal of the American Chemical Society, 118(1), 43-50. http://dx.doi.org/ 10.1021/ja953070s.

Hebrard, G., Blanquet, S., Beyssac, E., Remondetto, G., Subirade, M., \& Alric, M. (2006). Use of whey protein beads as a new carrier system for recombinant yeasts in human digestive tract. Journal of Biotechnology, 127(1), 151-160. http://dx.doi.org/10.1016/j. jbiotec.2006.06.012.

Hernández-Ledesma, B., Ramos, M., \& Gómez-Ruiz, J.Á. (2011). Bioactive components of ovine and caprine cheese whey. Small Ruminant Research, 101(1-3), 196-204. http://dx.doi.org/10.1016/j.smallrumres.2011.09.040.

Holt, C., Carver, J.A., Ecroyd, H., \& Thorn, D.C. (2013). Invited review: Caseins and the casein micelle: Their biological functions, structures, and behavior in foods. Journal of Dairy Science, 96(10), 6127-6146. http://dx.doi.org/10.3168/jds.2013-6831.

Huang, G., Gao, J., Hu, Z., St John, J.V., Ponder, B.C., \& Moro, D. (2004). Controlled drug release from hydrogel nanoparticle networks. Journal of Controlled Release, 94(2-3), 303-311.

Kane, R.S., \& Stroock, A.D. (2007). Nanobiotechnology: Protein-nanomaterial interactions Biotechnology Progress, 23(2), 316-319. http://dx.doi.org/10.1021/Bp060388n.

Kaya-Celiker, H., \& Mallikarjunan, K. (2012). Better nutrients and therapeutics delivery in food through nanotechnology. Food Engineering Reviews, 4(2), 114-123. http://dx.doi. org/10.1007/s12393-012-9050-3.

Khwaldia, K., Perez, C., Banon, S., Desobry, S., \& Hardy, J. (2004). Milk proteins for edible films and coatings. [Review]. Critical Reviews in Food Science and Nutrition, 44(4), 239-251. http://dx.doi.org/10.1080/10408690490464906.

Kilara, A., \& Vaghela, M.N. (2004). Whey proteins. In R.Y. Yada (Ed.), Proteins in food processing. Boca Ratin: CRC Press.

Kinsella, J.E., \& Whitehead, D.M. (1989). Proteins in whey: Chemical, physical, and functional properties. Advanced Food Nutrition and Research, 33, 343-438.

Kitabatake, N., Wada, R., \& Fujita, Y. (2001). Reversible conformational change in betalactoglobulin A modified with N-ethylmaleimide and resistance to molecular aggregation on heating. Journal of Agricultural and Food Chemistry, 49(8), 4011-4018.

Ko, S., \& Gunasekaran, S. (2009). In situ microstructure evaluation during gelation of $\beta$ lactoglobulin. Journal of Food Engineering, 90(2), 161-170. http://dx.doi.org/10. 1016/j.jfoodeng.2008.06.030

Kopeček, J. (2003). Smart and genetically engineered biomaterials and drug delivery systems. European Journal of Pharmaceutical Sciences, 20(1), 1-16. http://dx.doi.org/10. 1016/S0928-0987(03)00164-7.

Krochta, J.M. (1992). Control of mass transfer in foods with edible coatings and films. In R.P. Singh, \& M.A. Wirakartakasumah (Eds.), Advances in food engineering (pp. 517-538) (1st ed.). Boca Raton, FL: CRC Press.

Krochta, J.M. (2002). Proteins as raw materials for films and coatings: Definitions, current status and opportunities. In A. Gennadios (Ed.), Protein-based films and coatings (pp. 1-32). Boca Raton, FL: CRC Press.

Lei, L., Zhi, H., Xiujin, Z., Takasuke, I., \& Zaigui, L. (2007). Effects of different heating methods on the production of protein-lipid film. Journal of Food Engineering, 82(3), 292-297. http://dx.doi.org/10.1016/j.jfoodeng.2007.02.030.

Lesmes, U., \& McClements, D.J. (2009). Structure-function relationships to guide rational design and fabrication of particulate food delivery systems. Trends in Food Science $\mathcal{E}$ Technology, 20(10), 448-457. http://dx.doi.org/10.1016/j.tifs.2009.05.006.

Letchford, K., \& Burt, H. (2007). A review of the formation and classification of amphiphilic block copolymer nanoparticulate structures: Micelles, nanospheres, nanocapsules and polymersomes. European Journal of Pharmaceutics and Biopharmaceutics, 65(3) 259-269. http://dx.doi.org/10.1016/j.ejpb.2006.11.009.

Li, B., Du, W., Jin, J., \& Du, Q. (2012). Preservation of (-)-epigallocatechin-3-gallate antioxidant properties loaded in heat treated $\beta$-lactoglobulin nanoparticles. Journal of Agricultural and Food Chemistry, 60(13), 3477-3484. http://dx.doi.org/10.1021/ jf300307t.

Lin, C. -C., \& Metters, A.T. (2006). Hydrogels in controlled release formulations: Network design and mathematical modeling. Advanced Drug Delivery Reviews, 58(12-13), 1379-1408. http://dx.doi.org/10.1016/j.addr.2006.09.004.

Liu, F., \& Urban, M.W. (2010). Recent advances and challenges in designing stimuliresponsive polymers. Progress in Polymer Science, 35(1-2), 3-23. http://dx.doi.org/ 10.1016/j.progpolymsci.2009.10.002.

Livney, Y.D. (2010). Milk proteins as vehicles for bioactives. Current Opinion in Colloid $E$ Interface Science, 15(1-2), 73-83. http://dx.doi.org/10.1016/j.cocis.2009.11.002.

Machado, L.F., Pereira, R.N., Martins, R.C., Teixeira, J.A., \& Vicente, A.A. (2010) Moderate electric fields can inactivate Escherichia coli at room temperature. Journal of Food Engineering, 96(4), 520-527. http://dx.doi.org/10.1016/j. jfoodeng.2009.08.035. 
Madureira, A.R., Pereira, C.I., Gomes, A.M.P., Pintado, M.E., \& Xavier Malcata, F. (2007). Bovine whey proteins - Overview on their main biological properties. Food Research International, 40(10), 1197-1211. http://dx.doi.org/10.1016/j. foodres.2007.07.005

Matalanis, A., Jones, O.G., \& McClements, D.J. (2011). Structured biopolymer-based delivery systems for encapsulation, protection, and release of lipophilic compounds. Food Hydrocolloids, 25(8), 1865-1880. http://dx.doi.org/10.1016/j.foodhyd.2011.04.014.

Mchugh, T.H., \& Krochta, J.M. (1994). Milk-protein-based edible films and coatings. Food Technology (Chicago, IL, U. S.), 48(1), 97-103.

Medeiros, B.G. d. S., Pinheiro, A.C., Teixeira, J.A., Vicente, A.A., \& Carneiro-da-Cunha, M.G. (2012). Polysaccharide/protein nanomultilayer coatings: Construction, characterization and evaluation of their effect on 'Rocha' pear (Pyrus communis L.) shelf-life. Food and Bioprocess Technology, 5(6), 2435-2445. http://dx.doi.org/10.1007/s11947010-0508-0.

Medeiros, B.G., Souza, M.P., Pinheiro, A.C., Bourbon, A.I., Cerqueira, M.A., Vicente, A.A., et al. (2014). Physical characterisation of an alginate/lysozyme nano-laminate coating and its evaluation on 'Coalho' cheese shelf life. Food and Bioprocess Technology, 7(4), 1088-1098. http://dx.doi.org/10.1007/s11947-013-1097-5.

Medina, C., Santos-Martinez, M.J., Radomski, A., Corrigan, O.I., \& Radomski, M.W. (2007). Nanoparticles: Pharmacological and toxicological significance. British Journal of Pharmacology, 150(5), 552-558. http://dx.doi.org/10.1038/sj.bjp.0707130.

Moraru, C.I., Panchapakesan, C.P., Huang, Q.R., Takhistov, P., Liu, S., \& Kokini, J.L. (2003). Nanotechnology: A new frontier in food science. Food Technology, 57(12), 24-29.

Morris, V.J. (2010, March 31). Natural food nanostructures. In Q. Chaudhry, L. Castle, \& R. Watkins (Eds.), Nanotechnologies in food (1st ed.). Royal Society of Chemistry.

Mulvihill, D.M., \& Donovan, M. (1987). Whey proteins and their thermal-denaturation A review. Irish Journal of Food Science and Technology, 11(1), 43-75.

Oh, J.K., Lee, D.I., \& Park, J.M. (2009). Biopolymer-based microgels/nanogels for drug delivery applications. Progress in Polymer Science, 34(12), 1261-1282. http://dx.doi.org/10. 1016/j.progpolymsci.2009.08.001.

Palaniappan, S., \& Sastry, S. (2002). Ohmic heating. In V.K. Juneja, \& J.N. Sofos (Eds.), Control of foodborne microorganisms (pp. 451-460). New York: Marcel Dekker.

Parrott, D.L. (1992). Use of ohmic heating for aseptic processing of food particulates. Food Technology, 46(12), 68-72.

Pereira, R.N., Souza, B.W.S., Cerqueira, M.A., Teixeira, J.A., \& Vicente, A.A. (2010). Effects of electric fields on protein unfolding and aggregation: Influence on edible films formation. Biomacromolecules, 11(11), 2912-2918. http://dx.doi.org/10.1021/Bm100681a.

Pereira, R.N., Teixeira, J.A., \& Vicente, A.A. (2011). Exploring the denaturation of whey proteins upon application of moderate electric fields: A kinetic and thermodynamic study. Journal of Agricultural and Food Chemistry, 59(21), 11589-11597. http://dx doi.org/10.1021/Jf201727s.

Perez, O.E., \& Pilosof, A.M.R. (2004). Pulsed electric fields effects on the molecular structure and gelation of $\beta$-lactoglobulin concentrate and egg white. Food Research International, 37(1), 102-110. http://dx.doi.org/10.1016/j.foodres.2003.09.008.

Pérez-Gago, M.B., Nadaud, P., \& Krochta, J.M. (1999). Water vapor permeability, solubility, and tensile properties of heat-denatured versus native whey protein films. Journal of Food Science, 64(6), 1034-1037. http://dx.doi.org/10.1111/j.1365-2621.1999. tb12276.x.

Pethrick, R.A. (2004). Polymer physics. Edited by Michael Rubinstein and Ralph H Colby Oxford University Press, Oxford, 2003. ISBN 019852059X. pp 440. Polymer International, 53(9), 1394-1395. http://dx.doi.org/10.1002/pi.1472.

Pinheiro, A.C., Bourbon, A.I., Medeiros, B.G. d. S., da Silva, L.H.M., da Silva, M.C.H., Carneiroda-Cunha, M.G., et al. (2012). Interactions between K-carrageenan and chitosan in nanolayered coatings - Structural and transport properties. Carbohydrate Polymers, 87(2), 1081-1090. http://dx.doi.org/10.1016/j.carbpol.2011.08.040.

Prazeres, A.R., Carvalho, F., \& Rivas, J. (2012). Cheese whey management: A review. Journal of Environmental Management, 110(0), 48-68. http://dx.doi.org/10.1016/j. jenvman.2012.05.018

Ramos, O.L., Fernandes, J.C., Silva, S.I., Pintado, M.E., \& Malcata, F.X. (2012). Edible films and coatings from whey proteins: A review on formulation, and on mechanical and bioactive properties. Critical Reviews in Food Science and Nutrition, 52(6), 533-552. http://dx.doi.org/10.1080/10408398.2010.500528.

Ramos, O.L., Reinas, I., Silva, S.I., Fernandes, J.C., Cerqueira, M.A., Pereira, R.N., et al. (2013) Effect of whey protein purity and glycerol content upon physical properties of edible films manufactured therefrom. Food Hydrocolloids, 30(1), 110-122. http://dx.doi.org/ 10.1016/j.foodhyd.2012.05.001.

Reches, M., \& Gazit, E. (2003). Casting metal nanowires within discrete self-assembled peptide nanotubes. Science, 300, 625-627.

Reis, C.P., Neufeld, R.J., Ribeiro, A.J., \& Veiga, F. (2006). Nanoencapsulation I. Methods for preparation of drug-loaded polymeric nanoparticles. Nanomedicine: Nanotechnology, Biology and Medicine, 2(1), 8-21. http://dx.doi.org/10.1016/j.nano.2005.12.003.

Rodrigues, R.M., Martins, A.J., Ramos, O.L., Malcata, F.X., Teixeira, J.A., Vicente, A.A., et al. (2014s). Influence of moderate electric fields on gelation of whey protein isolate. Food Hydrocolloids(0). http://dx.doi.org/10.1016/j.foodhyd.2014.06.002 (in press).
Rudra, J.S., Dave, K., \& Haynie, D.T. (2006). Antimicrobial polypeptide multilayer nanocoatings. Journal of Biomaterials Science. Polymer Edition, 17(11), 1301-1315. http://dx.doi.org/10.1163/156856206778667433.

Sahiner, N., Alb, A.M., Graves, R., Mandal, T., McPherson, G.L., Reed, W.F., et al. (2007). Core-shell nanohydrogel structures as tunable delivery systems. Polymer, 48(3), 704-711. http://dx.doi.org/10.1016/j.polymer.2006.12.014.

Said, H.M., Abd Alla, S.G., \& El-Naggar, A.W.M. (2004). Synthesis and characterization of novel gels based on carboxymethyl cellulose/acrylic acid prepared by electron beam irradiation. Reactive and Functional Polymers, 61(3), 397-404. http://dx.doi. org/10.1016/j.reactfunctpolym.2004.07.002.

Sastry, S.K., \& Barach, J.T. (2000). Ohmic and inductive heating. Journal of Food Science, 65 , 42-46. http://dx.doi.org/10.1111/j.1750-3841.2000.tb00617.x.

Schmid, M., Dallmann, K., Bugnicourt, E., Cordoni, M., Wild, F., Lazzeri, A., et al. (2012). Properties of whey-protein-coated films and laminates as novel recyclable food packaging materials with excellent barrier properties. International Journal of Polymer Science, 2012, 7. http://dx.doi.org/10.1155/2012/562381.

Schuetz, Y.B., Gurny, R., \& Jordan, O. (2008). A novel thermoresponsive hydrogel based on chitosan. European Journal of Pharmaceutics and Biopharmaceutics, 68(1), 19-25. http://dx.doi.org/10.1016/j.ejpb.2007.06.020.

Shiga, T. (1997). Deformation and viscoelastic behavior of polymer gels in electric fields. Neutron spin echo spectroscopy viscoelasticity rheology, 134. (pp. 131-163). Berlin Heidelberg: Springer.

Silvestre, C., Duraccio, D., \& Cimmino, S. (2011). Food packaging based on polymer nanomaterials. Progress in Polymer Science, 36(12), 1766-1782. http://dx.doi.org/10. 1016/j.progpolymsci.2011.02.003.

Somchue, W., Sermsri, W., Shiowatana, J., \& Siripinyanond, A. (2009). Encapsulation of $\alpha$ tocopherol in protein-based delivery particles. Food Research International, 42(8), 909-914. http://dx.doi.org/10.1016/j.foodres.2009.04.021.

Sothornvit, R., \& Pitak, N. (2007). Oxygen permeability and mechanical properties of banana films. Food Research International, 40(3), 365-370. http://dx.doi.org/10.1016/j. foodres.2006.10.010

Souza, B.W.S., Cerqueira, M.A., Casariego, A., Lima, A.M.P., Teixeira, J.A., \& Vicente, A.A. (2009). Effect of moderate electric fields in the permeation properties of chitosan coatings. Food Hydrocolloids, 23(8), 2110-2115. http://dx.doi.org/10.1016/j.foodhyd. 2009.03.021.

Souza, B.W.S., Cerqueira, M.A., Martins, J.T., Casariego, A., Teixeira, J.A., \& Vicente, A.A. (2010). Influence of electric fields on the structure of chitosan edible coatings. Food Hydrocolloids, 24(4), 330-335. http://dx.doi.org/10.1016/j.foodhyd.2009.10.011.

Subirade, M., \& Chen, L. (2008, February 19). Food-protein-derived materials and their use as carriers and delivery systems for active food components. In N. Garti (Ed.), Delivery and controlled release of bioactives in foods and nutraceuticals (1st ed.). CRC Press.

Taylor, T.M., Davidson, P.M., Bruce, B.D., \& Weiss, J. (2005). Liposomal nanocapsules in food science and agriculture. Critical Reviews in Food Science and Nutrition, 45(7-8), 587-605. http://dx.doi.org/10.1080/10408390591001135.

Tokarev, I., \& Minko, S. (2009). Stimuli-responsive hydrogel thin films. Soft Matter, 5(3), 511-524. http://dx.doi.org/10.1039/b813827c.

Tunick, M.H. (2009). Whey protein production and utilization: A brief history. Whey processing, functionality and health benefits (pp. 1-13). Wiley-Blackwell.

Vermonden, T., Censi, R., \& Hennink, W.E. (2012). Hydrogels for protein delivery. Chemical Reviews, 112(5), 2853-2888. http://dx.doi.org/10.1021/cr200157d.

Walstra, P. (2003, November 24). Studying food colloids: Past, present and future. In E. Dickinson, \& T. v. Vlie (Eds.), Food colloids, biopolymers and materials (1st ed.). Royal Society of Chemistry.

Wang, W., Zhong, Q., \& Hu, Z. (2012). Nanoscale understanding of thermal aggregation of whey protein pretreated by transglutaminase. Journal of Agricultural and Food Chemistry, 61(2), 435-446. http://dx.doi.org/10.1021/jf304506n.

Weiss, J., Takhistov, P., \& McClements, D.J. (2006). Functional materials in food nanotechnology. Journal of Food Science, 71(9), R107-R116. http://dx.doi.org/10.1111/j.17503841.2006.00195.x

Xiang, B., Ngadi, M., Ochoa-Martinez, L., \& Simpson, M. (2011). Pulsed electric fieldinduced structural modification of whey protein isolate. Food and Bioprocess Technology, 4(8), 1341-1348. http://dx.doi.org/10.1007/s11947-009-0266-z.

Zhao, C. Zhuang X, He, P. Xiao, C. He, C., Sun, J., et al. (2009). Synthesis of biodegradable thermo- and $\mathrm{pH}$-responsive hydrogels for controlled drug release. Polymer, 50(18), 4308-4316. http://dx.doi.org/10.1016/j.polymer.2009.07.010.

Zimet, P., \& Livney, Y.D. (2009). Beta-lactoglobulin and its nanocomplexes with pectin as vehicles for $\omega-3$ polyunsaturated fatty acids. Food Hydrocolloids, 23(4), 1120-1126. http://dx.doi.org/10.1016/j.foodhyd.2008.10.008.

Zuniga, R.N., Tolkach, A., Kulozik, U., \& Aguilera, J.M. (2010). Kinetics of formation and physicochemical characterization of thermally-induced beta-lactoglobulin aggregates. Journal of Food Science, 75(5), E261-E268. http://dx.doi.org/10.1111/j.17503841.2010.01617.x 